\title{
La construcción del consenso político en la Argentina moderna. Poder político y sociedad civil en Buenos Aires, 1852-1861
}

\author{
Alberto R. Lettieri \\ UNIVERSIDAD DE BURNOS AIRES
}

\begin{abstract}
En este artículo se estudia el proceso de construcción de un nuevo consenso político en Buenos Aires durante el periodo 1852-1861, haciendo especial hincapié en el análisis del papel asignado a la opinión pública dentro del nuevo sistema de legitimación del régimen republicano.
\end{abstract}

$\mathbf{L}$ a construcción del régimen político en el siglo XIX ha constituido el objeto de un debate clásico sobre la historiografia argentina. Dentro de ese extenso proceso que se extiende entre la Revolución de - Mayo de 1810 y la sanción de la Ley Sáenz Peña en 1912 -que confirió un carácter secreto y obligatorio al sufragio universal-, la literatura institucional ha diferenciado dos grandes periodos, los cuales reconocen como punto de inflexión la batalla de Caseros $(3$ de febrero de 1852). Según la perspectiva canónica, el primero de ellos habría estado signado por la preeminencia de tendencias autoritarias y disolventes, expresadas en la fragmentación territorial que sucedió al agotamiento de la expansión revolucionaria, y en la emergencia de caudillos provinciales de origen rural, quienes a través de un conjunto de pactos recíprocos, habrían dado origen a un orden político confederal hegemonizado por la provincia de Buenos Aires y por su caudillo, Juan Manuel de Rosas, en el marco de un proceso de franco declive de la civilización. ${ }^{1}$

${ }^{1}$ Esta interpretación, ampliamente difundida, está inspirada en el Facundo. Civilización 
A diferencia de las sorprendentes transformaciones experimentadas en los terrenos de la economía o la demografía, por ejemplo, el sistema político de la segunda mitad del siglo XIX sería objeto de una evaluación mucho más modesta. En efecto, siguiendo los lineamientos prescritos por el publicista liberal tucumano Juan B. Alberdi, en diversos trabajos publicados durante su largo exilio en tiempos del rosismo, ${ }^{2}$ la versión canónica insistió en caracterizar al régimen político emergente como una "república aristocrática", expresión de un "autoritarismo progresista" que impulsaba el progreso económico a costa de cargar con una grosera ilegitimidad originada en una "no resolución de la crisis de participación, al bloquear la ampliación del espacio de ciudadanía. ${ }^{3}$ Si bien, para Alberdi, este cercenamiento de la libertad política no debería prolongarse indefinidamente, sino que, una

o barbarie de Sarmiento, de 1845 . Véase, Sarmiento, Facundo, 1971, en especial pp. 271330.

${ }^{2}$ A juicio de Alberdi, la Argentina posrosista debería conformarse con base en un estricto modelo, al que designaba como "república posible", que combinaba un generoso reconocimiento constitucional de las libertades civiles y económicas con un riguroso recorte de los derechos políticos. Las razones argumentadas resultaban, en teoría, contundentes: en tanto la garantía de las libertades civiles constituía un requisito indispensable para la captación de los capitales y mano de obra europeos que permitirían impulsar un rápido proceso de modernización de tono capitalista, una política demasiado activa e inclusiva sólo prometía, a sus ojos, la reedición a corto plazo del proceso de agitación pública que había fecundado al orden rosista. Halperín, Proyecto, 1978, pp. 55 y ss.

${ }^{3}$ Véase Terán, "Liberalismo", 1994, pp.28-29. vez constatada una modificación sustantiva de las condiciones socioeconómicas, la "república posible" debería dejar paso a la "república real", a través de una extensión de los derechos políticos; para la interpretación canónica ese paso sólo se daría con la sanción de la ley Sáenz Peña, en 1912. Montada sobre los requisitos del fraude y la violencia estructurales, la política en la Argentina moderna habría excluido la participación de la sociedad civil -una verdadera "política sin pueblo"-, adoptando una dinámica facciosa de manifiesto tono personalista y autoritario. De este modo, el liberalismo político no habría sido -de acuerdo con las expresiones de un ambiguo personaje de la época, Carlos D'Amico- sino un simple maquillaje pour l'exportation. ${ }^{4}$

Estas interpretaciones han sido puestas en cuestión en los últimos años. En lo referido a la etapa anterior a Caseros, los autores han impugnado aquellas caracterizaciones tradicionales sobre los caudillos federales que los definían como "déspotas" o "expresión de la barbarie rural", advirtiendo que, lejos de escapar a la sujeción a toda norma, ellos habrían manifestado un celoso respeto por las instituciones provinciales y por diversos derechos consuetudinarios que se remontaban a la época colonial, garantizando puntillosamente su vigencia, como en el caso de la Legislatura Provincial, la vida municipal, la Justicia, la milicia y la práctica regular del sufragio. Los estudios disponibles -referidos prefe-

${ }^{4}$ D'Amico, Buenos Aires, 1967, p. 173. 
rentemente a sus arquetipos más denostados, como Juan Manuel de Rosas o Facundo Quiroga- han demostrado, de manera suficiente, que el horizonte de ideas de la vida pública estuvo caracterizado por un republicanismo conservador, de raigambre clásica, profundamente celoso de las, jerarquías sociales e inspirado, en gran medida, en motivos religiosos.5 Estos elementos permitieron articular un original sistema de legitimación que combinó, en el caso del rosismo, periódicas demostraciones colectivas de subordinación a la autoridad carismática del líder -demandando el diseño de una compleja liturgia que combinaba motivos monárquicos y religiosos-, con un difundido ejercicio del sufragio, que permitía reafirmar institucionalmente la lealtad de la población masculina a través de la aprobación de las listas únicas de candidatos elaboradas por el propio Rosas.

Los. estudios recientes sobre el rosismo -y sobre el caudillismo en general- confirman, de todas formas, el profundo autoritarismo de la cultura política vigente, aportando una serie de matices y prácticas específicas que garantizaron tanto una consolidación definitiva del concepto de autoridad pública, como la imposición de hábitos de obediencia social. La incondicional aprobación brindada por sus adversarios más radicales -como Juan Bautista Alberdi o Domingo Faustino Sarmiento- a esta tarea de disciplinamiento, no constituye un dato menor al momento de estudiar las carac-

"Ternavasio, "Régimen", 1995; Myers, Orden, 1995. terísticas de la política de la época y los valores que la inspiraban. ${ }^{6}$

Pese a que diversos elementos de juicio permiten conjeturar la perduración y resignificación de algunos valores y prâcticas en la segunda mitad del siglo XIX, su estudio constituye todavía una tarea pendiente para la historiografía argentina contemporánea. Por el contrario, las contribuciones recientes -fundamentalmente para el periodo $1852-1880$, denominado tradicionalmente como de "organización nacional"-, han coincidido con el enfoque tradicional en subrayar la existencia de ese parteaguas de 1852, así como en privilegiar el estudio de los cambios y las características del proceso de modernización, dejando de lado el análisis de las continuidades. Sus diferencias, en cambio, se expresaron a través de la impugnación de uno de sus juicios más terminantes: el de la existencia, después de Caseros, de una "crisis de participación", producto del "bloqueo del espacio de la ciudadanía". En este caso, los autores han puesto en cuestión la adecuación de la perspectiva canónica-que entendía por participación política el ejercicio del derecho de sufragar-, al momento de analizar un sistema en construcción que poca fidelidad guardaba respecto del majority system anglo-francés. En tal sentido se afirmaba que, si bien el libre ejercicio del sufragio universal, sancionado en Buenos Aires en la temprana fecha de 1821, había encontrado diversos límites - como son la constante intromisión de las autoridades,

\footnotetext{
${ }^{6}$ Halperín, Proyecto, 1978.
} 


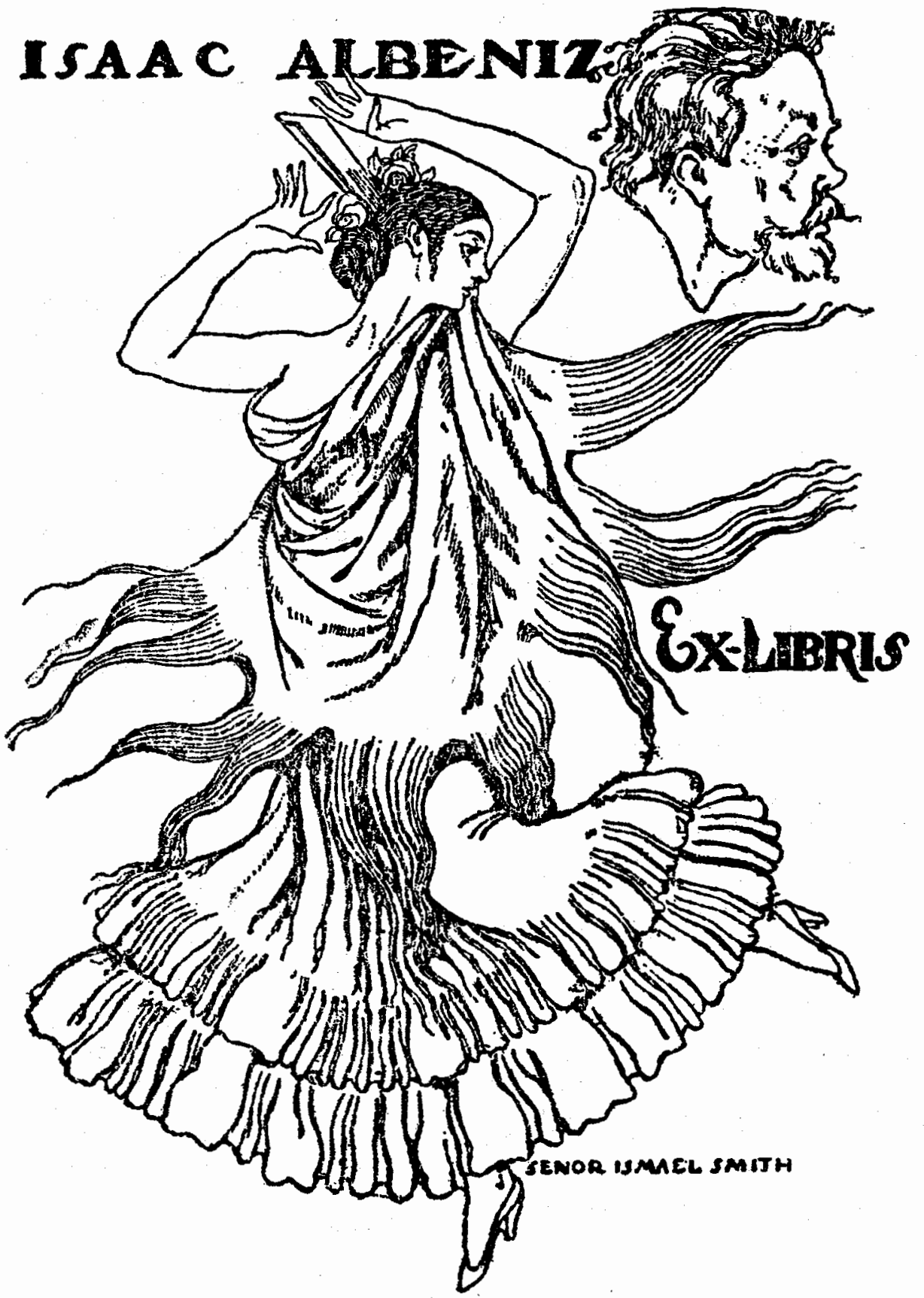


la vigencia de lealtades personales que trabaron la difusión de una lógica "moderna" de la representación o un elemental instinto de supervivencia de la población ante la creciente vio. lencia que desataban los comicios-, ello no autorizaba a inferir la formación, después de Caseros, de una "república sin pueblo". Por el contrario, se sostenía que la cuestión debía abordarse desde una perspectiva más amplia, una que tuviera en cuenta tanto las condiciones de producción de ese sufragio, como el análisis de ciertas formas de sociabilidad y participación informal que se manifestaban, en ese momento, con una enorme vitalidad. $^{7}$

En el caso del sufragio, Hilda Sábato propuso transformar la vía de ingreso tradicional a su estudio -expresada en la pregunta: ¿qué trabas se oponían al ejercicio del sufragio?-, por una interrogación en sentido positivo: ¿quiénes votaban?, y iqué características adquiría el proceso de producción del sufragio? Sus análisis pusieron en cuestión la existencia de una "república aristocrática" en sentido riguroso, al constatar que el sufragio no incluyó un mecanismo de selección jerárquica de los votantes, sino que, en su mayoría, los votantes efectivos habrian sido verdaderos profesionales que componían clientelas fuertemente vinculadas al empleo público y privado, caracterizadas por su extracción marginal y por el alto número de extranjeros -en teoría,

7 Sábato, "Ciudadanía", 1994; Sábato, "Elecciones", 1995; Sábato y Palti, “QQuién?", 1990; González, "Pedagogía", 1994. privados del derecho a voto- que las componían. La producción del sufragio, en tanto, incluía un largo proceso que se iniciaba con la convocatoria electoral y culminaba con la aprobación de los candidatos votados por el cuerpo respectivo, incluyendo un conjunto de etapas relacionadas con la selección de los candidatos y la confección de listas que se caracterizaban por una numerosa participación popular, contrastante con la verificada durante el comicio y con el proceso de imposición vertical de las candidaturas realizada por Rosas. ${ }^{8}$

Los estudios recientes sobre participación y sociabilidad en Buenos Aires desmintieron, asimismo, la existencia de esa vida política restringida y limitada a las elites tras la caída del rosismo, aconsejada por Alberdi y sancionada por los estudios tradicionales. En virtud de estos aportes, es. tamos en condiciones de afirmar que el rasgo característico de los nuevos tiempos parece haber sido la formación de una esfera pública de tono burgués -estrechamente vinculada al proceso de modernización socioeconómica de la ciudad-,' que comprendió el desarrollo de una nueva sociabilidad asociativa -clubes de emtretenimiento, salones de lectura, asociaciones profesionales, etc. $-{ }^{10}$ y la práctica activa y generalizada de ciertas formas de participación pública, informales y complementarias del sufragio, como la movilización pública y la pren-

• Sábato, "Elecciones", 1995; Sábato y Palti, "¿Quién?", 1990.

"Sábato, "Ciudadanía", 1994.

${ }^{10}$ González, "Pedagogía", 1994. 
sa escrita, la cual experimentó entonces una verdadera explosión. ${ }^{11}$

La confirmación de la existencia de una fluida relación entre sociedad civil y poder político, así como de una compleja trama que garantizó la participación política a través de diversas prácticas, permiten poner en cuestión el juicio canónico sobre la "grosera ilegitimidad", o "ilegitimidad endémica", que habría afectado al régimen político posterior a Caseros, inferida a partir del diagnóstico de "crisis de participación". Por el contrario, diversos indicios autorizan a postular que la legitimidad del régimen político en la segunda mitad del siglo XIX, fue producto de una combinación histórica particular entre jerarquías sociales, lealtades personales, ejercicio del sufragio, formas de participación informales y democracia directa.

En este artículo me propongo estudiar la construcción de esa nueva legitimidad para el régimen político emergente en Buenos Aires, a través de un proceso tan significativo como escasamente transitado por nuestra historiografía, que transcurre entre 1852-1861. Al respecto, debe indicarse inicialmente que, pese a lo prescrito por los publicistas de la época, lejos de conducir a la unidad e institucionalización definitiva de la república, la caída de Rosas abriría el camino hacia una nueva década de desencuentros, en la cual la Argentina experimentó la formación de dos Estados, la Confederación Argentina y el escindido Estado de Buenos Aires, cada uno de los cuales proclamaría constitucionalmente

"Sábato, "Ciudadanía", 1994. su propia soberanía. Caracterizada por la vigencia de una verdadera pax armada, en la cual, el acuerdo se alternó con violentos enfrentamientos militares, la primera década posrosista parece haber favorecido el desarrollo de una nueva forma de hacer política, donde la nueva clase política en formación convocaría frecuentemente a la movilización y la participación popular, ungiendo a la opinión pública y al sufragio en las fuentes de la legitimidad política. De este modo, es posible postular que, lejos de encontrarnos ante una "política sin pueblo", la frecuente interpelación de la ciudadanía habría registrado una llamativa respuesta, componiendo un escenario original cuya dinámica descansó sobre una síntesis entre continuidad e innovación de diversos valores, prácticas e identidades. La nueva legitimidad republicana, basada de este modo en el entramado de un nuevo consenso político, allanaría el camino de la consolidación del régimen político en la provincia escindida, encaminándola, a través de un sendero plagado de incertidumbres y contramarchas, hacia la obtención de una hegemonía política incuestionable a nivel nacional, tras la batalla de Pavón librada en septiembre de 1861.

A fin de desarrollar estas hipótesis, ordenaré mi exposición del siguiente modo: primero, haré un análisis, del proceso político desarrollado entre la batalla de Caseros y la formación de la República de Buenos Aires, haciendo especial hincapié en la redefinición de las alianzas sociopolíticas y las características de la nueva relación que se establecería entre la sociedad 
civil y el poder político; segundo, estudiaré la construcción de una nueva legitimidad republicana en Buenos Aires, los valores y prácticas que comprende ese proceso, prestando atención especial al nuevo consenso político, las condiciones que lo hicieron posible, y su evolución en estricta relación con el avance del proceso de unificación definitiva de la nación argentina; tercero, analizaré la dimensión coercitiva del nuevo consenso, y los límites al ejercicio de las libertades civiles, privilegiando el estudio de la prensa escrita; cuarto, conclusiones.

EL. IEGADO DE CASEROS:

ENTRE EL CAOS Y LOS ORÍGENES

DEL RÉGIMEN POLÍTICO MODERNO

\section{Los limites de una alianza}

La batalla de Caseros ha sido considerada, tradicionalmente, como un punto de inflexión en la historia argentina del siglo XIX. Según la perspectiva canónica, la victoria del Ejército Grande Aliado de América del Sur -compuesto por tropas de las provincias litorales argentinas $y$. del ejército del Brasil, exiliados liberales y algunos batallones orientales (uruguayos), financiados por el imperio paulista y bendecidos por las diplomacias de Gran Bretaña y Francia-, habría marcado el fin de un régimen despótico y atrasado, caldo de cultivo de la violencia y la anarquía, y el inicio de un proceso de organización nacional, que se extendería hasta 1880. Esta caracterización, sin embargo, no consigue superar una comprobación bas- tante pueril: en tanto la Confederación rosista había garantizado treinta años de orden y paz, sólo interrumpidos por circunstanciales reacciones armadas de los exiliados o intentos de acción directa de potencias extranjeras, su derrota dejaría paso a una larga década de desencuentros, retrasando la puesta en marcha del proceso de unificación e institucionalización definitiva de la república que encabezaba el programa de las fuerzas victoriosas.

En este momento, las coincidencias programáticas que habían posibilitado el forjamiento de la alianza político-militar que "pulverizó" al régimen de la federación, se mostraban patéticamente endebles ante la profunda heterogeneidad de los intereses políticos, económicos y sociales que aspiraban a comandar el proceso de transformación. En efecto, hermanados en su interés por un derrocamiento del adversario común, las razones que motivaban a los distintos actores conspiraban contra una prolongación de la alianza que consiguiese superar ese objetivo puntual. Por el lado del Imperio Brasileño, la preocupación estratégica que había motivado la consolidación del régimen rosista se agotaba con su destrucción, al tiempo que la nueva debilidad del orden interior en el territorio argentino abría las puertas para una nueva fase de su política expansiva en el cono sur, generando asimismo brillantes oportunidades de inversión para la banca paulista sobre el territorio liberado. En cuanto a Francia y Gran Bretaña, su reclamo tradicional de sanción de la libre navegación de los ríos interio- 
res, reiteradamente denegado por Rosas, sería inmediatamente satisfecho, conservando su tradicional influencia sobre los grupos dirigentes locales.

En el caso de las elites rioplatenses, las distancias se ampliaban, ya que la llegada del Ejército Grande no sólo introducía en la ciudad a un significativo grupo de liberales exiliados -más por sus ambiciones que por su número-, sino también a un jefe militar poco dispuesto a hacer las veces de convidado de piedra en el ajuste de cuentas que aquéllos se aprestaban a exigir, definiéndose así los trazos más gruesos de un ríspido escenario en el que el entramado de un consenso elemental entre los vencedores, las clases propietarias -sólidamente establecidas al amparo del régimen cáido-y las principales figuras políticas del rosismo, empecinadas en conseguir una inmediata inserción en el proceso de transición que se avecinaba, exigía concretar previamente profundos reacomodamientos.

De este modo, rápidamente el acuerdo inicial de los componentes nativos de la alianza vencedora sobre un programa común, devino en desacùerdo sobre la conducción de ese proceso de transformaciones. En ese contexto, el general Justo José de Urquiza, gobernador de la próspera provincia litoral de Entre Ríos y jefe del Ejército Grande, ostentaba la candidatura más firme para liderar el nuevo proceso, ya que a su condición de rico ganadero -que le permitió inicialmente encontrar puntos de contacto con los sectores propietarios bonaerenses-, sumaba un sólido liderazgo sobre las provincias argentinas -el cual le había posibilitado heredar sin objeciones la jefatura del Partido Federal, sucediendo al propio brigadier general, Juan Manuel de Rosas-, en tanto su jefatura era asimismo reconocida por una prestigiosa minoría, dentro del grupo de liberales exiliados en tiempos del rosismo, como Juan B. Alberdi, Juan M. Gutiérrez y Vicente F. López, deseosos de erradicar de raíz cualquier posibilidad de avance de un proceso de divisiones internas. Sin embargo, tras una aparente consolidación inicial, esta candidatura encontraría firme oposición en Buenos Aires, tanto de la porción mayoritaria de los retornados liberales, que aspiraban a obtener un rédito mucho más significativo de su aporte en la caída del rosismo del que Urquiza estaba dispuesto a concederles, como de los mismos sectores propietarios bonaerenses, que manifiestaban una notoria desconfianza ante la alternativa de reconocer el liderazgo político de un actor extraño a la provincia.

De este modo, solidaridades e identidades provinciales fuertemente arraigadas, que habían subsistido durante los largos años del rosismo, ocupando un modesto segundo plano tras del conflicto excluyente que enfrentaba a federales y unitarios, retornarían al centro de la escena. Rápidamente, la tradicional pretensión hegemónica de Buenos Aires y una llamativa determinación de los núcleos dirigentes del interior por impedir su cristalización, permitirían definir una nueva configuración política cuyas divergencias, como bien ha observado Tulio Halperín Donghi, no eran nuevas, resultan- 
do francamente anacrónicas respecto de los ideales de transformación asumidos por el conjunto de las fuerzas políticas y sociales que participaban en esta disputa. ${ }^{12}$ Sin embargo, pese a lo supuesto por los publicistas liberales, admiradores del orden y la disciplina social impuestos por Rosas, en. ese momento podía advertirse con claridad que su legado no había sido otro que un imponente conjunto de rivalidades y tensiones subyacentes, que ahora venían a hacer eclosión, condenando a la Argentina a una nueva década de violencia y secesión intestinas.

\section{El escenario de la nueva política:} la provincia de Buenos Aires.

Los relatos de los actores liberales retornados, escritos durante los meses que sucedieron a la caída del régimen rosista, presentan un cuadro marcadamente pesimista de la nueva situación en la ciudad de Buenos Aires: los 30000 hombres que componían las tropas de Urquiza apostados en los alrededores de la ciudad; la ejecución sin juicio previo de soldados desertores y sus cadáveres colgados en los árboles que sombreaban el camino que conducía a la antigua residencia de Rosas, en Palermo, que ahora era ocupada por su vencedor; su actitud de prescindencia ante los saqueos que atormentaron a la urbe porteña la noche misma del combate de Caseros, haciendo caso omiso de los ruegos

\footnotetext{
${ }^{12}$ Halperín, Proyecto, 1978, p. 57.
}

de personalidades locales y representantes diplomáticos, ${ }^{13}$ y su debilidad ante las presiones del ejército brasileno, que lo llevaron a retardar el ingreso de las fuerzas aliadas triunfantes hasta el 20 de febrero, a fin de hacerlo coincidir con el aniversario de su derrota en la batalla de Ituzaingó (1828), concretando así una ansiada revancha,${ }^{14}$ fueron señalados reiteradamente como los aspectos más visibles de una eficaz estrategia de disciplinamiento social, que inmovilizó inicialmente cualquier gesto de resistencia de la sociedad porteña.

La contundencia de los argumentos oculta, sin embargo, deliberadamente el asentimiento explícito otorgado inicialmente tanto por los políticos como por los denominados "sectores decentes" de la sociedad porteńa, empeñados en una especie de competencia por dejar constancia de su adhesión al nuevo caudillo, que los llevaba a convidarlo permanentemente a sus bailes y recepciones, y a trasladarse diariamente en masa a su residencia, atascando el camino suburbano que conducía a Palermo.

La subordinación de la primera sociedad porteña abonó un creciente autocratismo en las actitudes de Urquiza, quien explotaba en su beneficio las diferencias entre los diversos grupos que pretendían asegurarse sus favores para consolidar su posición. De este modo, no rechazaría a aquellas figuras políticas características del régimen depuesto, explotando su ad-

${ }^{13}$ Sarmiento, Campaña, 1957; Saldías, Historia, 1987, t. II, pp. 57-59.

${ }^{14}$ Paoli, Sarmiento, 1964, p. 125. 
hesión popular para fortalecer su propia base social en una ciudad en que la enorme mayoría de la población continuaba siendo indudablemente rosista, así como para debilitar la capacidad de presión de los grupos liberales que le acompañaron en la aventura del Ejército Grande. En tal sentido, su designación como gobérnador interino de Alejandro Vicente López y Planes -anciano autor del Himno Nacional que había integrado prácticamente sin interrupción las administraciones de signo diverso que se sucedieron en la Provincia, desde las lejanas jornadas de mayo de 1810 , tanto debido a sus fluidos contactos, como a su manifiesta falta de escrúpulos-, había significado una decisión fundamental, que le permitió combinar un gesto de convivencia inicial con su pretensión de mantener bajo atento control al Estado y a la política provincial. ${ }^{15}$

La respuesta de la sociedad porteña, que no había dudado en ungir un nuevo tirano en reemplazo del depuesto, echaba por tierra las expectativas del sector mayoritario, y más ambicioso, de los liberales retornados, quienes desde un principio habían especulado con el inmediato y voluntario retiro de Urquiza tras la batalla de Caseros. Su resentimiento, expresado inicialmente con sordina, llegaría rápidamente a oídos del general, quien reaccionaría incrementando el sesgo autoritario de su política, intentando imponer el uso obligatorio en Buenos Aires de la tradicional divisa punzó -símbolo histórico del Partido

\footnotetext{
${ }^{15}$ Lettieri, Vicente, 1995.
}

Federal- $\mathrm{y}$ asumiendo personalmente las relaciones exteriores -función desempeñada por Rosas: La posición a adoptar frente a la actitud de Urquiza agudizó la fragmentación de los principales referentes liberales, quienes compusieron dos grupos, uno de los cuales privilegió su adhesión al líder militar, remarcando el significado de una gesta libertadora que consideraban aún incompleta y asignando a Urquiza el carácter de hombre providencial para su concreción -entre quienes se destacaban Francisco Pico, Juan María Gutiérrez y Vicente Fidel López, hijo del gobernador, con la adhesión desde la distancia de Juan B. Alberdi-, ${ }^{16}$ y un segundo grupo que, de manera relativamente velada, abogaba por una solución menos consecuente, encabezado por el jefe reconocido de la emigración, Valentín Alsina, quien era secundado por Bartolomé Mitre, Estévez Seguí y otros que, como Vélez Sarsfield, no habían dudado en el momento de integrar la administración rosista.

\section{El germen de la debacle de Urquiza}

El aparente control ejercido sobre la sociedad porteña conduciría a Urquiza a impulsar una normalización de la situación institucional de la provincia, convocando para ello a elecciones para la Sala de Representantes. Esta decisión no revestía un carácter menor, ya que la Sala, encargada de designar al gobernador propietario, constituía el espacio institucional de

${ }^{16}$ Ibid. 
la política universalmente reconocido en Buenos Aires, y como tal había sido cuidadosamente preservado, incluso durante el mandato de Juan Manuel de Rosas, quien había fundado en su aprobación la legalidad del régimen que encabezaba. ${ }^{17}$ El propio Sarmiento, insospechado de mantener ningún tipo de simpatías hacia el rosismo, expresaba en este momento:

Dícese que no hay Constitución escrita en las provincias. Esto es cierto; pero no es menos cierto que hay una práctica, una escuela invariable, constante en todas ellas, que ni en tiempo de Rosas ha sido violada. Las atribuciones de la Sala, la responsabilidad de los ministros, la ley electoral, la dependencia del ejecutivo, todas estas formas constitucionales están en práctica. Rosas ha sido el más escrupuloso observante đe las formas, lo que dio a su gobierno esa pretensión de legalidad que él creía intachable, aunque la ilegitimidad fuese chocante. Ningún poder nuevo podía, pues, violar esas formas, que son las de todos los países constituidos. La Inglaterra no tiene Constitución escrita pero la práctica constitucional es tan severa que pasa ante las

\footnotetext{
${ }^{17}$ En este sentido debe entenderse la crítica valoración de Valentín Alsina, en sus editoriales durante su exilio en Montevideo, a la Sala de Representantes, considerándola rebajada a una "reunión de hombres, sin derecho alguno, que sólo puede verificarse cuando lo disponga el señor a quien han sentado sobre todas las leyes y solamente para entender en aquellos negocios que él les designa previamente, tal es el cuerpo representativo, el cuerpo legislativo, que ha cerca de catorce años existe en Buenos Aires". El Comercio del Plata, 27 de diciembre de 1848 .
}

otras naciones como el tipo y el modelo del gobierno constitucional. ${ }^{18}$

Ante la imposibilidad de acordar una lista única, dos eran las opciones que se presentaban a los votantes: la lista ministerial, organizada por el jefe de la emigración liberal, Valentín Alsina-quien retenía su cargo de ministro de Gobierno provincial pese a la evidente animadversión de Urquiza-, y la auspiciada por el caudillo entrerriano. Integradas en ambos casos por liberales y ex rosistas, las diferencias entre ambas eran mínimas, pero alcanzaban para someter a una prueba de fuego la pretensión de liderazgo de ambos. ${ }^{19} \mathrm{~A}$ fin de garantizar la victoria, el 11 de abril las tropas estacionadas en las afueras ingresaron a la ciudad, transitándola incansablemente y estableciéndose junto a los atrios. Pese a ello, el triunfo correspondería a la lista ministerial, resultado que permitía constatar la importancia decisiva que adquiría el control del aparato estatal -aún en escorzo, como en este caso-, al momento de asegurar una definición comicial favorable.

El resultado electoral no alcanzó para provocar un vuelco inmediato en la situación porteña, ya que finalmente la nueva Sala de Representantes debería ceder ante las presiones de Urquiza, designando como gobernador propietario a Alejandro Vicente López y Planes, hecho que provocaría la renuncia de Alsina. Sin embargo, el germen de la debacle del dominio de Urquiza ya estaba instalado. Las elec-

\footnotetext{
${ }^{18}$ Sarmiento, Campaña, 1957, p. 322.

${ }^{19}$ Ibid., p. 75.
} 
ciones de representantes sembraron dudas sobre la capacidad de Urquiza para hacer respetar sus decisiones, poniendo en cuestión una legitimidad de su autoridad que, derivada de una victoria militar, no había conseguido adquirir el atributo de la legalidad.

Perturbado por la derrota, Urquiza perdería la calma y, con ella, la caṕacidad para decodificar la evolución de la situación política en Buenos Aires. Decidido a consolidar su situación, redoblaría sus exigencias ante la Sala de Representantes, creyendo poder controlar la voz del disenso demandando la aplicación de medidas coercitivas sobre una prensa que, a diferencia de la etapa preelectoral, ya no consentía en atribuir a desatenciones y omisiones los gestos de autoritarismo desplegados por Urquiza, intentando garantizar de ese modo su supervivencia. ${ }^{20} \mathrm{La}$ gravedad de la situación, que entrañaba la amenaza del general de recurrir a mecanismos de acción más directos para imponer su voluntad, llevaría al joven diputado Bartolomé Mitre a presentar, el 17 de mayo de 1852, "un proyecto de ley sobre el uso y el abuso de la Imprenta en 95 artículos", argumentando que

[...] aunque su opinión era que el mejor remedio del abuso de la imprenta es dejarla en absoluta libertad, sin embargo, en el lugar que ocupa de diputado es legislador y no filósofo, por lo que había trabajado este proyecto. ${ }^{21}$

${ }^{20}$ Levene, Historia, 1940, p. 402.

${ }^{21}$ Representantes, Diario, 1852, p. 20.

\section{El liberalismo en ascenso}

La derrota electoral decidió a Urquiza a apurar su proyecto de organizar a la nación, de acuerdo con los lineamientos propuestos por Juan B. Alberdi en Las bases, escrito en 1852 y especialmente dedicado por su autor al vencedor de Caseros. ${ }^{22}$ Según este programa, la sanción de una Constitución debería ser el punto de partida para la instauración de un proceso de institucionalización nacional que crease las condiciones indispensables para un desarrollo material significativo, denunciando como sus principales adversarios a las situaciones de hecho y a la excesiva agitación de la vida política. Intentando evitar el desmadre del proceso encarado, Urquiza convocó inmediatamente a una reunión de gobernadores en la localidad de San Nicolás, provincia de Santa $\mathrm{Fe}$, a fin de sentar las bases para la reunión de un Congreso Constituyente encargado de redactar, finalmente, una Constitución nacional.

Dentro del círculo de allegados a Urquiza, la iniciativa encontró una calurosa recepción, con la única divergencia de Vicente F. López, quien evidenciaba seria preocupación, por un lado, respecto de los riesgos que podría suponer el alejamiento físico del general de la ciudad de Buenos Aires para asistir a la reunión y, por otro, de la oportunidad de sancionar de manera precipitada una Constitución que a su juicio debería ser un producto natural del paso del tiempo. ${ }^{23}$

\footnotetext{
${ }^{22}$ Alberdi, Bases, 1984.

${ }^{23}$ Lettieri, Vicente, 1995, p. 23.
} 
Su diagnóstico no resultaba errado, ya que la partida de Urquiza permitiría, por primera vez, el surgimiento de signos explícitos de rebelión ante su autoridad, protagonizados por algunos legisladores liberales en su calidad de editorialistas.

En efecto, comandada por Los Debates, cuyo redactor era el legislador liberal Bartolomé Mitre, y El Nacional, dirigido por Dalmacio Vélez Sarsfield, hábil legista que había superado sin esfuerzo la transición de Caseros, la prensa liberal insistía en impugnar la decisión del gobernador porteño López y Planes de concurrir al encuentro convocado por Urquiza sin haber solicitado la autorización previa de la Sala de Representantes. Poco después, las alarmantes noticias que llegaban sobre los términos del Acuerdo celebrado en San Nicolás contribuyeron a profundizar el descontento, destacándose la referida a los términos de la convocatoria de un Congreso Constituyente, en la cual se disponía una participación igualitaria de dos diputados por provincia, prescindiendo de su población o su poderío económi$\mathrm{co}^{24}$

El liberalismo porteño intentó entonces utilizar la expectativa generalizada para ampliar su base política, denunciando, a traves de la prensa, al Acuerdo firmado el 31 de mayo como un premeditado perjuicio a Buenos

\footnotetext{
${ }^{24}$ El artículo $5^{\circ}$ del Acuerdo de San Nicolás disponía que: "Siendo todas las provincias iguales en derechos, como miembros de la nación, queda establecido que el Congreso Constituyente se formará con dos diputados por cada provincia." Acuerdo de San Nicolás, en Sampay, Constituciones, 1975 , p. 333.
}

Aires, $y$ convocando en defensa de sus intereses a la sociedad toda. La estrategia pronunciaba el deslizamiento verificado por el discurso de $E l$ Nacional y de Los Debates, los que ahora interpelaban a la sociedad en su conjunto apelando a una identidad provincial común, prescindiendo de las diferencias partidarias. Pocos días después, El Nacional se felicitaba de la reacción expresada por una opinión pública que, por primera vez en largos años, había salido de su letargo para expresar su descontento:

La opinión pública comenzó a nacer cuando vio un acuerdo o un tratado que se celebraba en formas inusitadas, que nadie quería adoptar ni defender: tratado sin los precedentes legales, escondidos estudiadamente del Cuerpo Legislativo, y que debía aparecer sólo como documento oficial cuando se hallara en el pueblo el vencedor de Rosas; como si ese tratado no tuviera otra cosa con que ser demostrado que con el poder de las armas. ${ }^{25}$

El retorno a Buenos Aires enfrentó al gobernador porteño con una ciudad que había experimentado un profundo cambio.

Sometido a las críticas de la prensa ante la falta de publicidad oficial del Acuerdo celebrado, y presionado por una Sala que exigía someter a discusión la aprobación de las gestiones realizadas, López y Planes y sus ministros debieron someterse a una feroz requisitoria parlamentaria durante los días 22 y 23 de junio. Tanto el aspecto de la Sala como el espíritu de los

${ }^{25}$ El Nacional, 21 de junio de 1852. 
legisladores constituían el mejor indicador de que la ausencia de Urquiza no había pasado en vano: colmadas las gradas por una infalible barra que no habría de abandonar en adelante su participación en las sesiones, a la cual se sumaban los tenderos -quienes decidieron el cierre de sus locales como contribución a la jornada cívica- y los notables, que respaldaron con su firma las peticiones que solicitaban la discusión de lo actuado, ${ }^{26}$ el destino del elenco gobernante parecía estar trazado de antemano. Por primera vez, después de Caseros, el discurso liberal conseguía articularse con un sentimiento de temor y profunda reprobación que atravesaba a la sociedad porteña. ${ }^{27}$ Sin embargo, lo que pareció ser un triunfo contundente de la facción liberal -la renuncia al elenco gubernamental-, no llegaría a ser fecundo, debido a la rápida reacción de Urquiza, quien dispuesto a no tolerar un avance en la situación política del liberalismo, decidió provocar un giro terminante dentro de la política porteña.

\footnotetext{
26 "La opinión popular se manifestó en dos notas, una apoyando la conducta seguida por la Legislatura, la otra -encabezada por Gregorio Araoz de Lamadrid- pidiendo en nombre de la paz pública esperar la vuelta de Urquiza y V. López para discutir sobre lo acordado en la reunión de gobernadores. Las dos notas se depositaron en Secretaría para recibir allí las firmas de los que quisiesen subscribirlas y ser enseguida impresas y repartidas al público." Levene, Historia, 1940, p. 384.

${ }^{27}$ Sarmiento, Campaña, 1957, p. 54.
}

\section{Los rosistas a la escena}

Sin dar tiempo a la consolidación de los sucesos, Urquiza dispuso la clausura de los periódicos opositores, el cierre de la Sala de Representantes, el destierro de los principales diputados opositores -entre los que se contaban V. Alsina, Mitre y Vélez Sarsfield- y la reposición de las autoridades renunciantes, argumentando actuar con base en lo dispuesto por el Acuerdo de San Nicolás que, en su artículo 14, garantizaba la estabilidad de los gobernadores, a pesar de su rechazo por la Sala de Representantes provincial. ${ }^{28}$ Sin embargo, la efectividad de su acción demandaba contar con un partido que le permitiese asegurarse una base política local ante la clausura de las instancias institucionales. En ese momento, sólo el rosismo estaba disponible.

Apostando a un acercamiento, Urquiza repuso a los antiguos funcionarios del rosismo, incluso en la conducción de la Guardia Nacional; perdonó a quienes había condenado a muerte tras la batalla de Caseros; derogó el decreto de embargo de los bienes de Rosas, sancionado por el ministro Alsina a su expresa solicitud, y conformó un Consejo de Estado,

28 "Art. 14.- Si, lo que Dios no permita, la paz interior de la república fuese perturbada por hostilidades abiertas entre una u otra provincia, o por sublevaciones armadas dentro de la misma provincia, queda autorizado el encargado de las Relaciones Exteriores para emplear todas las medidas que su prudencia y acendrado patriotismo le sugieran, para restablecer la paz. [...]". Acuerdo de San Nicolás, en Sampay, Constituciones, 1975, p. 334. 


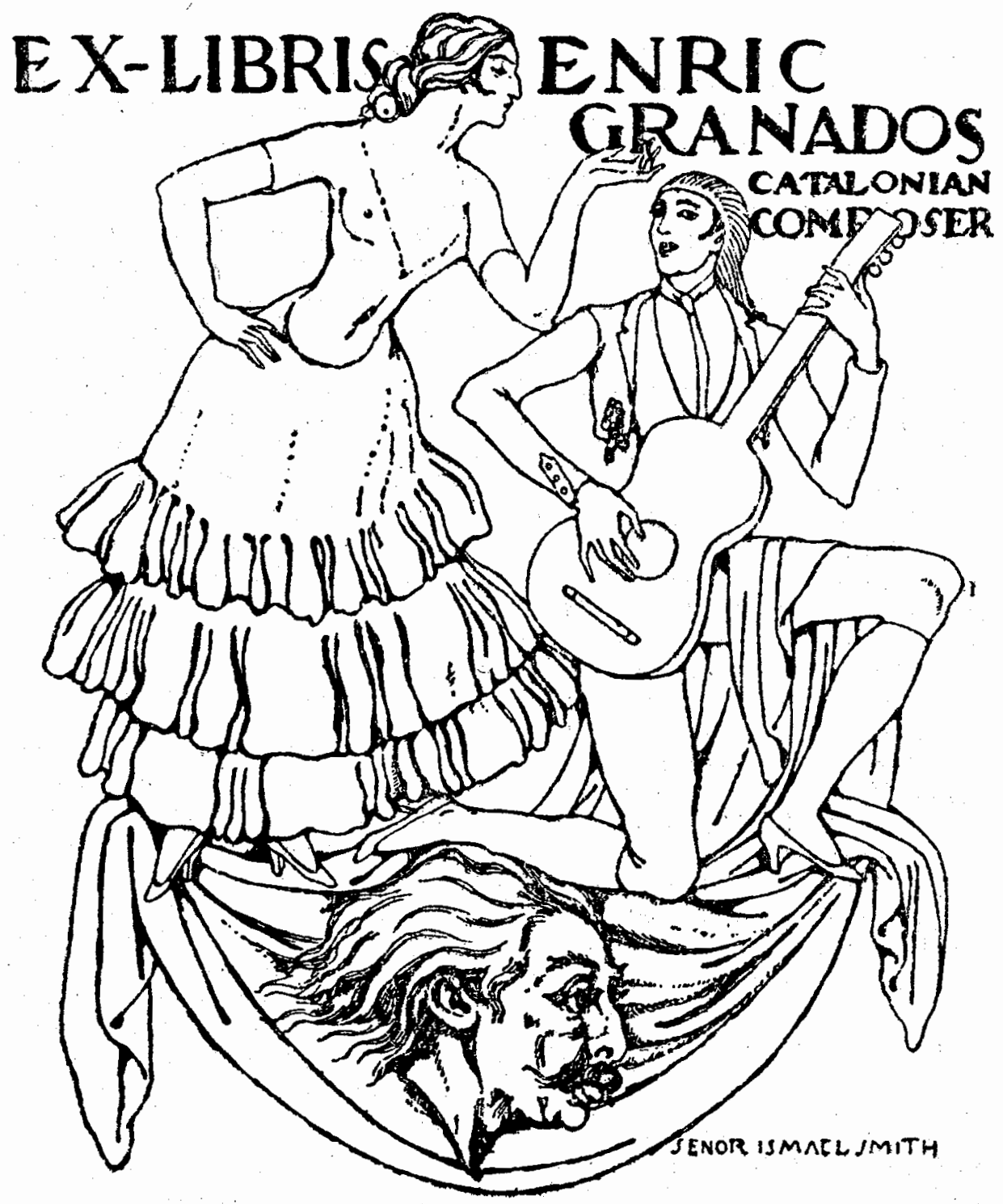


integrado por las principales figuras del rosismo, como Anchorena, Arana, Baldomero, Irigoyen y Lahitte. Sin embargo, si bien la nueva estrategia de Urquiza permitía recuperar cierta representación pública a las figuras más destacadas del rosismo, la misma no se traducía en verdadera eficacia política, en tanto que los cargos restituidos no alcanzaban el ámbito del ejército o los puestos claves de la Confederación, como ministerios o embajadas. En cuanto al Consejo, una única reunión alcanzaría para demostrar su incapacidad para poner límites a la autoridad de Urquiza, quien sin adversarios de fuste a la vista, se dedicaba a saquear en forma sistemática las rentas de la Aduana para financiar su política nacional, contrastando con la sobria y ordenada gestión de Rosas. ${ }^{29}$

Tras la definitiva renuncia de López y Planes, poco tiempo después de su reposición, Urquiza asumió personalmente la gobernación, encubriendo tras una actitud más tólerante el creciente autoritarismo de su estilo político. La limitada apertura incluyó un levantamiento de la clausura de los medios opositores, a condición de que morigerasen al extremo sus juicios sobre la acción oficial, y de la autorización de un retorno de los legisladores exiliados, aunque la Sala continuó sin funcionar. ${ }^{30}$

Este gobierno autoritario, que establecía sus relaciones con la sociedad civil a través del rosismo, constituyó finalmente la estrategia más adecuada entre las esbozadas por Urquiza para

${ }^{29}$ Sarmiento, Campaña, 1957, p. 134.

${ }^{30}$ Levene, Historia, 1940, p. 432. dominar Buenos Aires. Sin embargo, su éxito sería contingente, en tanto que una nueva evaluación inadecuada de la situación porteña, conduciría al definitivo fin de la dominación del general entrerriano. En efecto, juzgando su situación porteña como suficientemente consolidada, Urquiza delegaría el mando en su lugarteniente, el general Galán, el 8 de septiembre, para trasladarse a Santa Fe a fin de revestir al acto de inauguración de las sesiones de la Convención Constituyente con su sello personal, y controlar de cerca a los legisladores. Sólo tres días después, el gobernador interino debería emprender una fuga desenfrenada intentando poner a salvo su propia vida.

\section{La Revolución de Septiembre}

El 11 de septiembre, Buenos Aires despertó con una sorprendente novedad: durante la madrugada, un movimiento cívico militar había puesto fin a la dictadura de Urquiza y sus acólitos. La prensa porteña, en tanto, elogiaba un resuelto movimiento de la opinión pública que, superando las vejaciones, se había levantado en defensa de la legalidad provincial. José Luis Bustamante, periodista liberal exiliado en los años del rosismo, resumía los sucesos:

Los ciudadanos corrían voluntariamente a los cuarteles y a la plaza, tomando las armas para sostener el nuevo orden de cosas, ofreciendo sus recursos sin reserva para ocurrir a los gastos que demandasen las operaciones que se emprendían desde aquellos momen- 
tos. El pueblo de Buenos Aires y el Ejército se identificaban en un mismo pensamiento, en una sola idea. Proclamaban los principios legales de la Provincia y defendían sus derechos con la opinión y la espada. ${ }^{31}$

Sin embargo, pese a la imaginación y las plumas diestras de los publicistas liberales que describieron para la posteridad el proceso revolucionario, como el citado Bustamante o Sarmiento, la asonada del 11 de septiembre no constituyó el resultado de una irrupción material de la opinión pública en la escena política, sino, en todo caso, una prueba contundente de la capacidad de seducción del oro porteño sobre las conciencias y rivalidades internas de los jefes confederados destacados en Buenos Aires. ${ }^{32}$ No sería, por cierto, una práctica excepcional, ya que, de manera reiterada durante la década de 1850 , el soborno del enemigo constituyó una de las más efectivas garantías de la autonomía provincial. Tampoco lo sería la estrategia adoptada por el liberalismo progresista: favorecido por el arbitraje de las clases conservadoras que financiaron la empresa, hastiadas tanto de los desastres consumados por Urquiza en su manejo de los fondos porteños, como de su creciente autoritarismo, ${ }^{33}$ el recurso de interpelar a una amplia opinión pública adjudicándole los méritos de sus empresas, prometía brindarle una relativa independencia de criterio ante los

${ }^{31}$ Bustamante, Memorias, 1853, p. 168.

${ }^{32}$ Saldias, Historia, 1987, t. II, p. 133.

${ }^{33}$ Levene, Historia, 1940 , p. 352; Sarmiento, Campaña, 1957, p. 128. sectores propietarios, procedimiento cuyas primeras huellas podían rastrearse ya en las Jornadas de Junio. En adelante, y gracias a su comprobada efectividad, el vínculo que ligaba los destinos del régimen político en formación y la opinión pública sería fortalecido en cada oportunidad disponible.

La elección de Valentín Alsina como nuevo gobernador propietario, el 30 de octubre, que implicaba un reconocimiento hacia el líder de los emigrados y verdadero organizador de la asonada, permitiría establecer los límites de la operación liberal que había intentado privilegiar las identidades provinciales sobre las partidarias. En efecto, las resistencias a su designación patentizaban la pervivencia de hondas heridas no sanadas en el cuerpo social provincial, a punto tal que, antes de que transcurriese un solo mes en el calendario y alegando responder a un supuesto "clamor popular", el coronel Hilario Lagos -de raigambre rosista- reclamaría el 28 de noviembre su renuncia, mientras aseguraba a su reciente adversario de Caseros, el general Urquiza, la inminente concurrencia de la Provincia a la organización nacional.

En este momento resulta posible comprobar un desgajamiento dentro del antiguo rosismo entre los políticos urbanos y los antiguos jefes militares. En tanto los primeros, luego de la renuncia de Alsina, no dudaron en integrar un gabinete de coalición con sus pares liberales atendiendo al poco promisorio futuro que les ofrecía en ese momento un acercamiento a Urquiza -en vista del papel secunda- 
rio que éste les había asignado durante el periodo que había concluido el 11 de septiembre-, los militares veían con espanto la alternativa de subordinarse a la autoridad de uno de los héroes más caros dentro del panteón liberal, el general José María Paz, ${ }^{34}$ a cargo de las armas provinciales, de quien tanta sangre $y$ odios mutuos los separaban.

Ante el fracaso de las negociaciones de paz, Lagos inició el sitio de Buenos Aires. Una vez más, las identidades partidarias pasaban a un segundo plano, en tanto que el conflicto secular entre ciudad y barbarie, Buenos Aires e interior, dominaba al nuevo imaginario político citadino. Hasta el 20 de junio, toda la campaña -incluidas las parroquias porteñas de Montserrat, Balvanera, Concepción, Pilar y San Telmo-, sería controlada por el jefe rebelde, quien pretendió refrendar la legitimidad de su liderazgo recurriendo a la antigua práctica de levantar actas, entre los vecinos de cada distrito, en las que se le confería autoridad militar. Ante la contundente respuesta obtenida, Lagos decidió montar una administración provincial paralela, encabezada por los liberales urquicistas Francisco Pico y Vicente F. López, y convocar, ante la jura de la Constitución Nacional el 25 de mayo de 1853, una Convención Provincial para que resolviese sobre la cuestión de la incorporación a la nación. ${ }^{35}$.

${ }^{34}$ Véase Levene, Historia, 1940, p. 348; Sáenz, República, 1979, p. 134.

${ }^{35}$ Véase Saldías; Historia, 1987, t. II, p. 142.
Debido a la desesperante situación atravesada por la ciudad, el sitio bonaerense permitió profundizar su integración político-social, licuando momentáneamente las profundas diferencias históricas entre las facciones gracias a la acción conjunta en la defensa de sus figuras más destacadas, como el rosista Torres y el liberal Mitre. Asimismo, esto favoreció la trama de una estrecha ligazón entre gobernantes y gobernados, en tanto la participación común en la milicia, la movilización pública y un discurso integrador de la prensa permitieron debilitar el encasillamiento impuesto por las jerarquías sociales.

Aun cuando el sitio de Lagos, combinado por vía fluvial por la flota confederada, habría de desplomarse súbitamente el 20 de junio, una vez más, $y$ en virtud de los milagros operados por el oro y el papel moneda porteños, esa frontera material y simbólica entre mundo urbano y mundo rural no habría de disolverse a lo largo de la década. En efecto, para los porteños la campaña no dejaría de revestir un carácter de zona de riesgo en la que tendrían lugar nuevos levantamientos rebeldes, la acción destructiva de las tribus indígenas adecuadamente cooptadas por Urquiza -que habría de retrotraer las fronteras provinciales a las cercanas orillas del río Salado durante la mayor parte del periodo-, y la instalación de las tropas de la Confederación luego de la batalla de Cepeda, en 1859, en cuya incómoda proximidad la nueva "ciudad luz" en construcción encontraba un fabuloso disparador que le permitía renovar su cohesión interna. 
LA CONSTRUCCIÓN DE UNA NUEVA LEGITIMIDAD REPUBLICANA EN BUENOS AIRES

Las bases de un nuevo consenso: de las Jornadas de Junio al fracaso del sitio de Buenos Aires

La derrota de los sitiadores de Buenos Aires dejaba a las fuerzas políticas nacionales en situación expectante. En ese momento podía confirmarse que las prevenciones de Alberdi sobre los riesgos que implicaba la reinstalación de una agitada vida política para la consolidación institucional y material de la nación, no resultaban erradas. Si bien, por una parte, no podía desconocerse que esa vida política había renacido como una respuesta a las tendencias autocráticas que caracterizaban al estilo de mando del general Urquiza, no resultaba posible, sin embargo, extraer como único saldo de este proceso un triunfo de la libertad ante los intentos de expansión de un autoritarismo estatal: otras inspiraciones e intereses mucho más inmediatos y concretos-como, por ejemplo, la exclusión y el papel marginal que ofrecía el Libertador a liberales disidentes y antiguos rosistas, respectivamente, dentro del contexto nacional, un temor compartido a la expropiación de las rentas provinciales o bien la federalización del territorio urbano para establecer allí la sede definitiva del Estado Nacional-, eran los que finalmente habían conducido inicialmente a la Revolución de Septiembre y luego a la victoria de las fuerzas de la resistencia.

En efecto, durante su breve periodo de dominio sobre Buenos Aires,
Urquiza había logrado una síntesis insospechada durante los treinta años que le habían precedido, aunque, para sus ambiciones, lamentablemente en su contra. Liberales y rosistas -con la sola excepción de su rama militar-, contando con la aprobación activa de las clases propietarias y el conjunto de la sociedad civil porteña, habían conseguido postergar sus diferencias para emprender la empresa común de liberar a la provincia de la autoridad del general entrerriano. La amenaza del adversario común, expresada inicialmente en la dominación de Urquiza y, luego, en el sitio por vía terrestre y fluvial, constituyó un fabuloso disparador para la formación de un nuevo consenso sociopolítico basado en la integración de actores y prácticas y la resignificación de símbolos e identidades de diversa procedencia.

En tal sentido, ya durante las Jornadas de Junio resultaba posible advertir el interés explícito, por parte de la prensa liberal opositora, de consolidar bases sociales más firmes para su política, recurriendo a la presentación de indicadores del descontento social escasamente relevantes como pruebas irrefutables del renacimiento de una opinión pública socialmente inclusiva, que parecía abandonar su largo silencio para rebelarse ante el despojo a que era sometida la provincia. Esta posición, defendida con énfasis en la Sala de Representantes por el círculo de legisladores encabezado por Valentín Alsina -y que incluía a los redactores Mitre y Vélez Sarsfield-, era impugnada por un grupo de liberales que, tras soportar un largo destierro y 
participar moralmente en la campaña del Ejército Grande, se habían escindido del tronco mayoritario, manifestando su explícita adhesión a Urquiza. Entre ellos, Vicente Fidel López - hijo del gobernador López y Planes- aparecía como su vocero político más coherente, destacándose en los debates de junio por la solidez de sus posiciones. ${ }^{36}$ En esa ocasión, López identificó como el gran mal que aquejaba a la República Argentina, a la escisión entre la propiedad y el pensamiento ilustrado, la cual conducía regularmente a resolver las diferencias por una vía convulsiva:

El gran problema, señores, que hoy tenemos que resolver, es el de incrustar materia bruta dentro de la Constitución. En Norteamérica y en Inglaterra, y en todo país constituido, la opinión, a la vez que es opinión pública, es fuerza material, y por eso es sólido el edificio. Entre nosotros no ha sido así hasta ahora; por lo general, la opinión ilustrada está separada, no está unida con la fuerza; [...] esa falta de cohesión y de principios comunes, o de hechos consumados, nos ha hecho incapaces de decidir nuestras cuestiones políticas de otro modo, que en esa vía convulsiva en que, por desgracia, se traducen todas las disposiciones que entre nosotros afectan la política. ${ }^{37}$

Tras acusar a sus opositores de demagogos e irresponsables, López pro-

${ }^{36}$ Lettieri, Vicente, 1995, p. 32.

${ }^{37}$ Sala de Representantes de la Provincia de Buenos Aires, sesión del 22 de junio de 1852 , en Ravignani, Asambleas, 1937, t. Iv, p. 393. fundizaba el sesgo conservador del pensamiento liberal argentino, aconsejando la pertinencia de tomar en cuenta únicamente las opiniones de los actores y grupos dotados de reconocido poder moral, oponiéndose de plano a la prédica de Los Debates y $E l$ Nacional, periódicos empeñados en fortalecer la base social del liberalismo opositor auspiciando una ampliación de la caja de resonancia de la política, estrategia que evaluaba como decididamente suicida.

[...] yo desconfiaría siempre -señalaba V. F. López- de eso que se llama espíritu público, así como del sentimiento de la Provincia cuya interpretación o autoridad está siempre entre nosotros al arbitrio de todos los partidos [...]

Nosotros, en esta nueva época, debemos tomar por otro lado la cuestión del espíritu público. En todas las provincias existe hoy el poder moral de un nombre a quien, para emprender la constitución, debemos tomar por base de acción.

[...] el espíritu público de los grandes pueblos es otra cosa, consiste en la actividad reglada de la opinión, en el movimiento regular y tranquilo de las fuerzas colectivas, y no en ese fatalismo de las convulsiones que jamás hacen otra cosa que preceder a la postración o a la inercia. ${ }^{38}$

Significativamente, los sucesos desautorizaron inmediatamente la tesis de López, quien se vio obligado a renunciar como ministro provincial, junto con el resto del gabinete, ante la presión de los legisladores, la acti-

${ }^{38}$ Ibid., p. 394 
tud amenazante de los tenderos y la heterogénea audiencia que asistió al célebre debate, $;^{39}$ ésta supuso una versión en escorzo de la opinión pública que comenzaría a expresarse tras la asonada del 11 de septiembre, de carácter ampliado y crecientemente relevante en términos políticos.

En efecto, durante los meses del sitio porteño, tanto la relación cotidiana entre gobernantes y gobernados que promovieron las tareas de la defensa, como el tratamiento entre pares que la Guardia Nacional oponía a las jerarquías sociales que privaban en la sociedad civil, favorecieron el desarrollo de comportamientos más igualitarios. Asimismo, debido a las peculiares condiciones en que se desarrollaba, la práctica política adquirió una alta dosis de informalidad, adoptando incluso ciertos mecanismos asociados con la democracia directa, particularmente en lo referido a la legitimación de liderazgos. Estos procedimientos serían aceptados, e incluso alentados, por la clase política en formación, en tanto que esa capacidad de acuerdo se revertía en este momento hacia la opinión pública, legitimando inmediatamente su papel rector dentro de la política porteña y constituyendo un preciado argumento para que sustentara aquélla un importante grado de autonomía frente a las presiones de los sectores propietarios.

La nueva política reconocía como una de sus prácticas más características la renovada prensa escrita, cuya elevada retórica apuntaba a definir un

${ }^{39}$ Lettieri, Vicente, 1995, p. 35. nuevo imaginario político de matriz republicana que revalorizaba la identidad provincial, y que presentaba las decisiones políticas adoptadas como respuestas racionales al autoritarismo, fundándolas en la evolución de los juicios -e incluso, en la acción directa- de la opinión pública. De este modo, forzando el contraste con el personalismo tradicional de la política porteña, la victoria sobre Urquiza y la refundación de la autonomía provincial eran presentados como el producto de una acción colectiva de Buenos Aires, cuya dimensión mítica equiparaba sin esfuerzos a la gesta revolucionaria fundadora de $\mathbf{1 8 1 0}$.

Ningún pensamiento mezquino, personal, ni estrecho; ninguna mira de intereses individuales, ni de partido -afirmaba el periodista José Luis Bustamante- entraba en el plan que guiaba en aquellos momentos al pueblo y al Ejército. Tratábase únicamente de restablecer la libertad para todos, sin acordarse de federales, ni de unitarios, ni de libertadores, ni de ninguna otra entidad que representase pretensiones de otro género. El patriotismo más puro guiaba en aquella ocasión la opinión pública, con tanta altura y desinterés como el memorable 25 de mayo de $1810 .{ }^{40}$

\footnotetext{
${ }^{40}$ Bustamante, Memorias, 1853 , p. 124. En sentido similar se expresa Sarmiento: "Buenos Aires había sido testigo y actor desde 1810 de cambios, revoluciones, motines y alzamientos populares. Ninguno, empero, tenía el carácter del de 11 de septiembre. Aquí no había partido vencido, no había gobierno dislocado, no había división de clases, ni la campaña contra la ciudad, ni los rosistas contra los unitarios. Galán en retirada, todo estaba terminado; porque
} 
Esa inspiración inicial de la opinión sería considerada como el punto de partida para la reconciliación entre los partidos tradicionales, cuyos dirigentes -continuando con el relato mítico-se verían obligados a deponer sus diferencias para ponerse a la altura de ese clamor popular. El 18 de septiembre, en el marco de una imponente puesta en escena, las principales figuras del liberalismo y el rosismo, Valentín Alsina y Lorenzo Torres, sellarían la unidad, en una imponente velada celebrada en el Teatro Coliseo.

Grande era la actividad que se desplegaba en aquellos momentos por las autoridades públicas y por los ciudadanos todos, disputándose el honor de manifestar su decisión por la causa legal de la Provincia.

Allí se patentizó de la manera más pública y solemne, la uniformidad de vistas sobre el movimiento del 11 ; reconociendo en él la causa de todos los partidos políticos, la bandera de todas las opiniones y el centro de reunión de todos los patriotas. Era esa reunión una especie de culto público que la opinión general, robustecida por la unión, rendía al grande y famoso acontecimiento que habia restablecido en la Provincia el orden legal, su dignidad y libertad. La reunión fue númerosísima [...] y la patria era el único pensamiento que dominaba los espíritus y las opiniones todas. ${ }^{41}$

Galán era el gobierno, Galán era Urquiza, Galán era la conquista. [...] Así pues, la revolución tenía la sanción del común asentimiento, la santidad de una ablución de las pasadas faltas y de la humillación presente [...]", Sarmiento, Campaña, 1957, p. 356.

${ }^{41}$ Bustamante, Memorias, 1853, p. 189.
El sitio de Lagos que le sucedió permitiría instalar, dentro del imaginario en formación, la noción fundamental de ciudad sitiada. En su transcurso, tanto la acción coordinada entre las facciones, como las medidas adoptadas -en especial la convocatoria de la Guardia Nacional-, admitieron una traducción inmediata dentro del imaginario provincial, operación en la cual, la prensa, superando los abanderamientos políticos, habría de jugar un papel decisivo, al resaltar insistentemente el compromiso de unidad asumido por la dirigencia cívico-militar ante la agresión externa. Asimismo, el sitio daría origen a la creación de una nueva mística guerrera, en que destacaba la figura del ciudadano-armado -ya no del soldado, como en el pasado-, guardián de la integridad territorial $y$, sobre todo, de la libertad y el honor provincial. La nueva virilidad de los defensores de la Provincia resultaba indisociable de la condición del porteño, atravesando de este modo el tejido social y los abanderamientos partidarios, y pudiendo sintetizarse en la representación de los leones de la Guardia $\mathrm{Na-}$ cional, alabados en periódicos y sueltos, y eternizados en el folletín Camila o la virtud triunfante, compuesto especialmente en ese momento por el poeta José Mármol. El ministro Bartolomé Mitre no perdería la oportunidad de relatar su propia experiencia ante la declaración de sitio, en una clave que le permitía integrar al conjunto de la sociedad porteña, incluso a los mismos parientes de Rosas: 


\section{SECUENCIA}

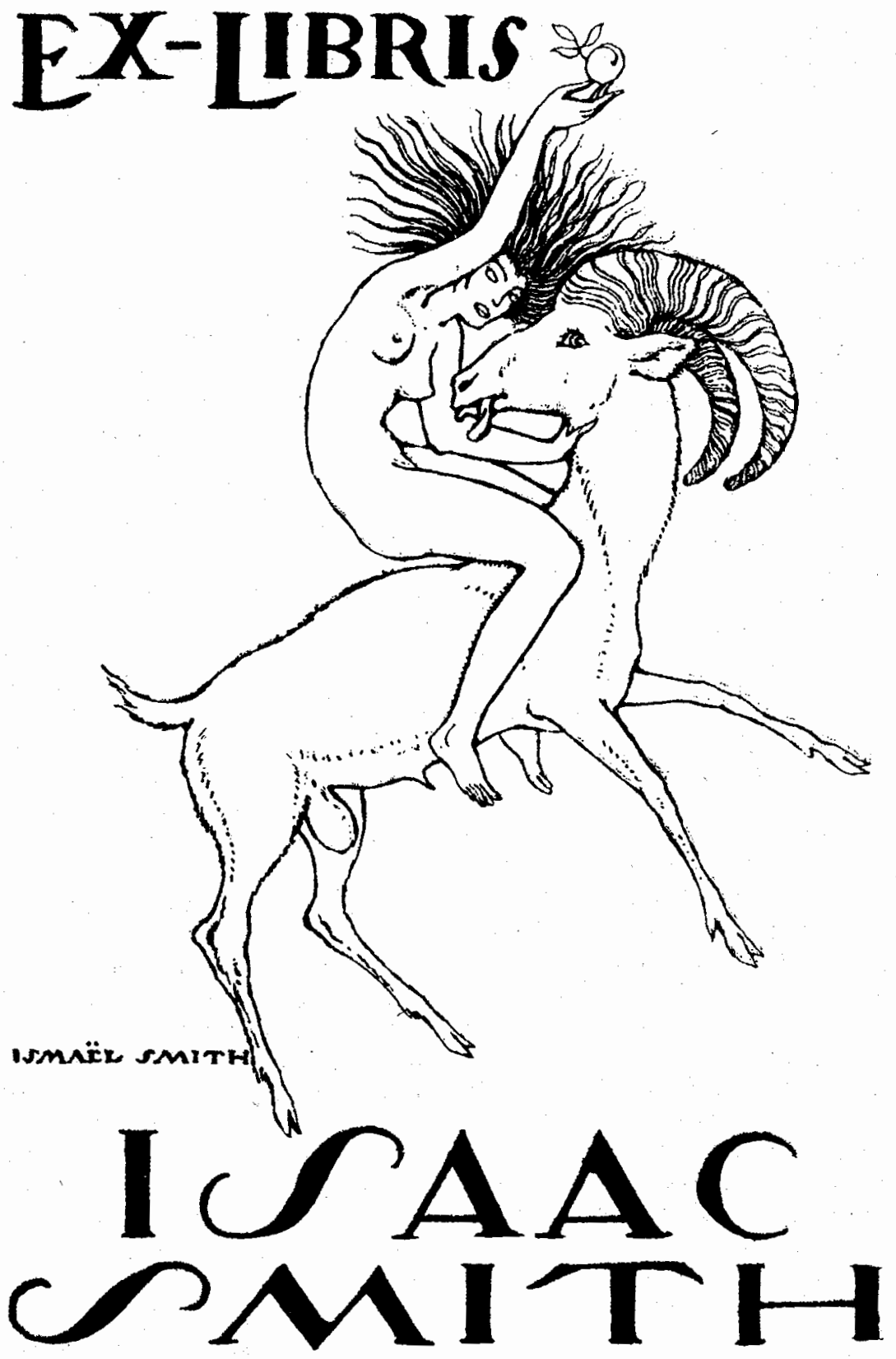


A caballo una vez y con los pies bien afirmados sobre los estribos, me quité en media calle el frac negro de ministro y me puse la casaca militar que me trajo un sobrino de Rosas, que quiso ser mi ayudante. Otro sobrino de Rosas me alcanzaba $\mathrm{mi}$ espada y $\mathrm{mis}$ pistolas [...]

Proclamé en seguida a veinte guardias nacionales en la esquina del Coliseo. Los hijos de Florencio Varela, inspirados por el valor cívico de su ilustre padre, contestaron mi proclama golpeando el tambor con brazo varonil. Noventa corazones valerosos de noventa guardias nacionales, latían al compás del toque de alarma y me seguían por la calle 25 de Mayo, en medio de una procesión de mujeres que salían a las puertas con lágrimas en los ojos para darnos la última despedida.

[...] a la tarde de ese mismo día, hombres, mujeres y niños pueden venir a pasear a la plaza del Retiro bajo la protección de la intrépida guardia nacional de Buenos Aires, que se había reconcentrado bajo mis órdenes. ${ }^{42}$

Nuevamente, como en el caso de la Revolución de Septiembre, el triunfo del oro porteño que clausuró el asedio de Lagos sería adjudicado a la opinión pública. Sin embargo, en ese momento, esa opinión pública había dejado ya de ser una invención de las dúctiles plumas liberales rioplatenses, para convertirse en el indicador más visible de una nueva "cultura de la movilización" 43 auspiciada por el conjunto de la dirigencia porteña, la cual fundaba en ella su propia legiti-

${ }^{42}$ Carta del general Mitre al doctor don Juan Carlos Gómez en La Tribuna, 16 de diciembre de 1869.

${ }^{43}$ Sábato, "Ciudadanía", 1994. midad. En efecto, ligada íntimamente al proceso de verdadera explosión asociativa iniciado después de Caseros, por el que clubes de diversión, sociedades literarias y asociaciones profesionales, venían a sumarse a la sociabilidad tradicional de las pulperías y las parroquias, ${ }^{44}$ la reiterada convocatoria de la movilización popular irá convirtiendo rápidamente en realidad esa presencia de la opinión pública en la vida política. De este modo, si bien la velada del Coliseo -organizada por la Comisión de Hacendados para celebrar la Revolución del 11 de Septiembre-, había sido destinada todavía a un público más selecto, su versión popular, un imponente desfile que incluyó la entrega de medallas alegóricas y premios en metálico a las tropas confederadas sobornadas -sumadas ahora a la causa de Buenos Aires- y a las milicias porteñas, con la heterogénea composición de su heterogéneo público, permite identificar el punto de partida de una nueva forma de hacer política, en la cual los escenarios públicos habrían de constituir una de sus principales y más características tribunas. ${ }^{45}$

La respuesta elaborada por la dirigencia porteña ante la amenaza directa de las tropas confederadas se sustentó en una decidida promoción de la identidad bonaerense, la cual sobrevoló las diferencias partidarias privilegiando la integridad de la provincia. Para ello, la definición de un nuevo imaginario que adjudicaba una capacidad de legitimación excluyente

\footnotetext{
${ }^{44}$ González, "Pedagogía", 1994.

${ }^{45}$ Saldías, Historia, 1987, t. II, p. 224.
} 
a la opinión pública permitió presentar a la heterogénea dirigencia porteña como una interlocutora que legitimaba su derecho al mando sometiéndose a sus dictados. Asimismo, esa identidad porteña reconoció como su contracara, su otro/antagonista, a la barbarie, síntesis de la tríada, compuesta por el general Urquiza, los militares rebeldes -con Hilario Lagos a la cabeza- y las tribus indígenas (a cuya amenaza y saqueos estructurales se sumaban su incorporación negociada a los ejércitos confederados en los momentos decisivos $\mathrm{e}$, incluso, el establecimiento de un mercado de cautivos a mediados de la década), la cual reconocía como su expresión simbólico/espacial a la campaña. Frente a esa representación, la imagen elaborada por Mitre, representando a la ciudad sitiada como a una cautiva blanca atada y de rodillas en las tolderías de las pampas, resultó, seguramente, la estilización más lograda de un sentimiento de temor compartido por ese público ampliado que concurría presuroso a las convocatorias de movilización, firmemente convencido de que, en la inestable evolución del equilibrio nacional, estaba en juego mucho más que sus derechos políticos.

\section{LA CONSTITUCIÓN DE 1854:}

UNA REPÚBLICA AUTÓNOMA Y SOBERANA

La presencia física de Urquiza y de las tropas confederadas en las afueras de Buenos Aires había permitido alcanzar un consenso entre las fuerzas políticas, tradicionalmente antagónicas, de esa ciudad, con la aprobación crecientemente activa de la opinión pública. Sin embargo, una vez superada esa amenaza inminente, el futuro podía auscultarse con cierto recelo, habida cuenta de la intolerante tradición política que había exhibido la provincia durante casi medio siglo de vida independiente. Sólo una razón, indudablemente determinante, permitía alentar cierta dosis de optimismo: a diferencia de Caseros, cuando el hundimiento del régimen rosista había despojado a las fuerzas aliadas de buena parte de los motivos que habían permitido su unión, ahora la rendición de las fuerzas sitiadoras no implicaba, en manera alguna, el fin de las graves amenazas que acotaban las diferencias entre las fuerzas porteñas. De todas formas, no escapaba a la dirigencia que el factor determinante que había alentado esa particular "fusión" entre liberales y rosistas había sido la presencia de un adversario común y la situación de conflicto armado afrontada por la provincia, convirtiendo a la urbe, como reiteradamente había sucedido en las décadas anteriores, en una verdadera ciudad sitiada. La relativa paz modificaba drásticamente el escenario, y resultaba ahora indispensable fortalecer las bases de ese consenso, a fin de preservar la integridad provincial.

Según se ha indicado, aun cuando uno de los puntos esenciales del acuerdo entre las fuerzas integrantes del Ejército Grande, y ciertamente el más importante entre los liberales exiliados y Urquiza, hubiese sido el inmediato dictado de una Constitución de alcance nacional de acuerdo 
con lo sugerido por Sarmiento en su Argirópolis, de 1850, y corroborado por Juan B. Alberdi en Las Bases, de 1852, ello no significaba, en modo alguno, la ausencia de una práctica republicana y legalista a orillas del Plata. Reiteradamente, la dirigencia de la época ha destacado las profundas raíces que ligaban a la Sala de Representantes provincial, su institución política fundamental, con el viejo Cabildo colonial, convirtiéndola en el símbolo incuestionable de la autoridad pública. ${ }^{46}$ En efecto, su funcionamiento no había sido descuidado por ninguna de las administraciones que tuvieron lugar a partir de 1821, a pesar de la procedencia sociopolítica profundamente heterogénea que caracterizó, por ejemplo, a la ideología rivadaviana en los años 20 -con sus manifiestas raíces benthamianas-, y al autoritarismo-populista del rosismo.

Sin embargo, una vez superada la etapa de la amenaza directa de las fuerzas confederadas -que concluyó con el levantamiento del sitio, y en la cual los mecanismos de legitimación informal ocuparon un papel decisivo dentro de la vida política porteña-, la necesidad de adaptar al naciente régimen político a los futuros tiempos de relativa calma induciría a las elites provinciales a buscar soluciones en esa tradición legalista. De este modo, en la sanción de la nueva Constitución Nacional por parte del Congreso de la Confederación Argentina, el 25 de mayo de 1853, no fue sorprendente que la respuesta ideada por las elites porteñas para reafirmar su propia

\footnotetext{
${ }^{46}$ Chiaramonte, "Vieja y nueva", 1995.
}

autonomía consistiera en la redacción de una Constitución provincial, que sintetizaba esa tradición republicana colocando como base del sistema político a la Sala de Representantes, devenida en Legislatura bicameral.

Sin embargo, de la adopción de esta solución constitucional, tradicionalmente propuesta por los unitarios y sus continuadores liberales, no debe inferirse una negación de la filosofía profunda que había regido los actos del rosismo. En efecto, en ese momento podía confirmarse, con la reinstalación de ese imaginario político y ese discurso público que privilegiaba la causa provincial, que la negativa de Rosas a sancionar una norma fundamental de alcance nacional había respondido ante todo a razones de estricto pragmatismo. De este modo, en tanto que, desde una posición hegemónica a nivel nacional, su dictado hubiera significado más un límite que un beneficio para los intereses de Buenos Aires, en ese momento, en que las autoridades porteñas sólo eran capaces de asegurar su control sobre un territorio limitado -transitado regularmente por tropas confederadas, tropas rebeldes desgajadas del antiguo rosismo y tribus salteadoras-, su redacción expresaba, de manera contundente, una pretensión manifiesta de ejercer su propia soberanía: lo que estaba en juego era el papel de Buenos Aires en el contexto nacional, y en esto, que se anteponía a las diferencias políticas, las fuerzas porteñas estaban acordes en afirmar -con mínimas excepciones- que la única alternativa posible a la hegemonía era la secesión. 
Significativamente, el proyecto original de sanción de una nueva Constitución sería presentado por Nicolás Anchorena, miembro de la principal familia de hacendados porteños y figura destacada del régimen rosista, el 26 de enero de 1853, durante el sitio de Buenos Aires. En su artículo inicial contenía una contundente descripción de la grave situación que atravesaba la Provincia como consecuencia de la brutal política de Urquiza:

La Provincia de Buenos Aires protesta ante Dios, ante las naciones todas de la cristiandad, y muy especialmente ante los gobiernos signatarios del convenio de 21 de noviembre de 1851 , su majestad el emperador del Brasil y el gobierno de la República Oriental del Uruguay, y ante sus hermanas las provincias que integran la República Argentina, contra la guerra insidiosa que el general D. Justo José de Urquiza le hace, promoviendo una rebelión que ha removido los criminales más famosos, que por desgracia abriga esta provincia, y con éstos, violenta a los pacíficos habitantes de la campaña a que engrosen sus filas, fomentando $y$ auxiliando dicha rebelión, causando diariamente la efusión de sangre y mortandad de los nacionales, afligiendo con el hambre la población inocente por el entredicho de víveres, destruyendo su riqueza, talando sus cosechas, consumiendo y destrozando sus ganados de toda especie, arruinando establecimientos valiosos de campaña, paralizando su industria y mejoras materiales, obstruyendo su comercio, espantando la población, llevando cautivos al Entre-Ríos muchos padres de familia, reteniéndolos y obligándolos por la muerte a que le sirvan como sol- dados veteranos, finalmente asolando a esta provincia. ${ }^{47}$

Si bien, en ese momento, el contenido de la propuesta apuntaba a fundamentar la pretensión porteña de decidir sobre su propia autonomía, el proyecto definitivo, redactado por una comisión compuesta por las principales figuras del liberalismo y el rosismo, y aprobado presurosamente por la Sala de Representantes en 1854, avanzaría mucho más allá, sancionando la reasunción de la soberanía provincial y consolidando, de este modo, los ideales y valores locales y republicanos que la lucha previa había permitido consagrar en el imaginario colectivo. El particular alineamiento que se establecería en esta discusión permitió alcanzar un contundente acuerdo entre rosistas y liberales encabezados por sus figuras más combativas -Nicolás Anchorena y Valentín Alsina- para aprobar: rápidamente, y de manera entusiasta, la nueva Constitución.

La nota discordante se manifestaría en las objeciones formuladas por aquella vieja gloria del panteón unitario, el general José C. Paz, y el ascendente Bartolomé Mitre, quienes cuestionaron la capacidad de la Provincia para reasumir su soberanía. En el caso de Mitre, la ocasión resultaría propicia para presentar su característico argumento de "preexistencia de la nación", desarrollado en detalle en su Historia de Belgrano y de la independencia argentina, publicada en 1857, aunque, en ese momento, sin mayor éxito.

\footnotetext{
${ }^{47}$ Representantes, Diario, 1853 ; p. 4.
} 
Las posiciones esgrimidas permiten confirmar el notable cambio experimentado tras la batalla de Caseros. En efecto, detrás de la aparente reinstalación, con motivo del tratamiento del articulado Constitucional, de aquel tradicional debate entre federación y confederación que había inspirado con ardor las políticas de unitarios'y federales durante la primera mitad del siglo, pueden advertirse ahora al menos dos diferencias fundamentales: la primera remite a ese nuevo giro político que experimenta la provincia, en virtud de su comprometida situación en el contexto nacional, que permite integrar en una misma retórica confederacionista - de la que no están ausentes algunas intervenciones radicales exigiendo, incluso, la independencia de Buenos Aires- tanto a rosistas como a una amplia mayoría liberal. La segunda, en tanto, apunta a la existencia de un consenso generalizado, dentro de las fuerzas políticas y sociales porteñas, sobre una especie de derecho natural de la Provincia a ejercer la conducción nacional, que convertía en ese momento a la cuestión de fondo, confederación/federación, a dos estrategias alternativas -separarse para negociar la reincorporación desde una posición de poder, o bien llevar adelante esas tratativas más sutilmente, desde dentro mismo de la Confederación- para alcanzar un mismo fin: la hegemonía nacional.

A tal punto esas distancias sólo significaban ahora un disenso puntual dentro de un acuerdo mayor, que su resonancia política no conduciría a fragmentaciones partidarias inmediatas dentro del tronco liberal, ni mu- cho menos a una agria disputa armada, como había sucedido en un pasado que ahora parecía mucho más distante de lo que los hechos se empeñarían en demostrar. De este modo, pese a su posición divergente, Bartolomé Mitre no se vio obligado a renunciar a la administración provincial, ni tampoco se entorpeció su pertenencia al círculo liberal liderado por V. Alsina. Por el contrario, la transcripción constitucional de una síntesis entre tradiciones políticas provinciales y una generosa concesión de derechos civiles a la altura de los nuevos tiempos, expresaba las bases del nuevo consenso entre fuerzas políticas históricamente antagónicas, estableciéndose así las reglas de un nuevo juego político en el que, sin embargo, aquella informalidad característica de su etapa formativa -entre las Jornadas de Junio y la derrota del sitio de Buenos Aires- seguiría desempeñando un papel decisivo.

\section{El juego interno de las facciones porteñas: entre el fin del consenso y la unificación definitiva de la nación}

Una vez superada la situación crítica, y electo un nuevo gobernador provincial, Pastor Obligado, en 1853, con un gabinete de coalición, las elecciones de representantes de 1854 presentaron, por primera vez después de Caseros, una competencia entre las nuevas facciones porteñas, denominadas popularmente como "chupandinos" -ex rosistas- y "pandilleros" -liberales. El acto electoral se carac- 
terizó por un ejercicio poco disimulado del fraude, que dejó como balance principal para las fuerzas políticas, la necesidad de asegurar su control sobre el Estado provincial, aún en escorzo, para decidir en el futuro sobre los resultados comiciales.

La consolidación de la situación porteña se sumaba, en ese momento, a la escasa disposición de Urquiza para renovar su política expansiva sobre Buénos Aires, en un momento en que la debilidad de la economía confederada se develaba como estructural. Fruto de esa situación de relativa distensión, los Pactos de Convivencia, firmados entre la Confederación y Buenos Aires en 1854 y 1855 , serían presentados como el punto de partida de una nueva época de paz y prosperidad, que habría de posibilitar una integración definitiva, no traumática, del cuerpo de la nación, en un plazo indefinido. Sin embargo, los sucesos inmediatos se encargarían de demostrar que la violencia no sería fácilmente desterrada del suelo argentino.

En efecto, una vez superada, momentáneamente, con la firma de los tratados de Convivencia la condición de ciudad sitiada, el liberalismo porteño habría de abocarse a una formidable ofensiva contra los antiguos rosistas, destrozando el consenso faccioso en su intento por desterrarlos de la escena pública. En tal sentido, las elecciones de representantes de 1856 y 1857 , de las cuales saldría la Asamblea que debería designar al nuevo gobernador provincial, estuvieron plagadas de violencia y amenazas, instalando oscuras prácticas que no desa- parecerían de la gestas electorales de la segunda mitad del siglo XIX. La evaluación de vencedores y vencidos permite comprobar la gravedad de los hechos. Por ejemplo, condenando la "injerencia sistemada del gobierno en la elección de representantes", el senador y periodista "chupandino" Nicolás Calyo relataba su versión del acto electoral de 1856:

Esa injerencia ilícita empezó hace tres o cuatro meses por la destitución de empleados bajo el pretexto de que eran torristas. [...] El objeto era alarmar a la opinión y buscar el pretexto para plantear una coacción abierta o disimulada según el caso permitiera. [...]

Vinieron después las correrías nocturnas del comandante Sotelo, los atropellamientos de domicilio, etc.: y todo esto lo supo el gobierno; no sólo porque la prensa se lo dijo en alta voz, sino porque algunos amigos del gobierno le hicieron presente que, autorizando esos desacatos, abría el camino a una tiranía futura. [...]

A esos soldados que mandaba Sotelo para aterrorizar al pueblo se les pagaban 15 pesos por noche, que hacían 450 pesos por hombre, faltando así al presupuesto, y a algunos oficiales 20 pesos [...]

Es sabido que el jefe de Policía soltó a uno de esos asesinos de los más audaces, que llevó preso el pueblo, porque tenía una tarjeta del Club Libertad. [...]

¿No somos porteños los opositores? ¿No tenemos el derecho de elegir nuestros representantes? ¿Hay privilegios que puedan pertenecer a una sola fracción del pueblo? ${ }^{48}$ 5-6. 


\section{TORTOLA VALENCIA}

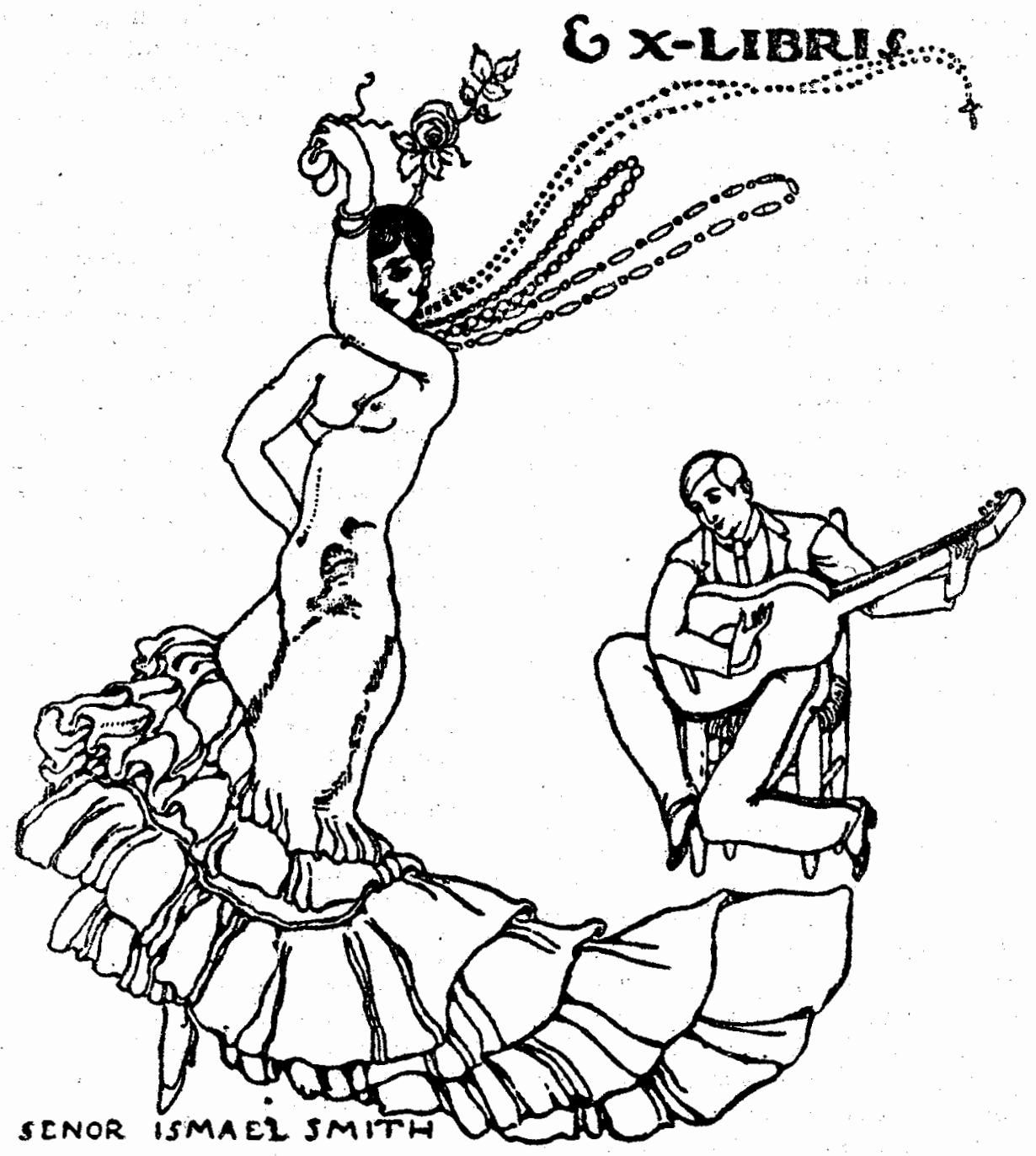


$\mathrm{Al}$ año siguiente, Sarmiento se ufanaba, en carta dirigida a su pariente Domingo de Oro -la que caería finalmente en manos de Urquiza, provocando escozor al ser publicada en todo el país-, de la estrategia aplícada por el Partido Liberal para obtener la victoria en los comicios de 1857 :

Fue tal el terror que sembramos en toda esa gente -la oposición- con estos y otros medios (establecimos en varios puntos depósitos de armas y municiones, encarcelamos como unos veinte extranjeros complicados en una supuesta conspiración; algunas bandas de soldados armados recorrían de noche las calles de la ciudad acuchillando y persiguiendo a los mazorqueros) que el 29 triunfamos sin oposición.

Su conclusión era lapidaria:

la audacia y el terror, empleados hábilmente, han dado este resultado admirable e inesperado.[...] el miedo es una enfermedad endémica en este pueblo; ésta es la gran palanca con la que siempre se gobernará a los porteños; manejada hábilmente producirá infaliblemente los mejores resultados. ${ }^{49}$

Valiéndose de su dominio del aparato del Estado provincial, el Partido de la Libertad emprendería, de este modo, una política de terror y persecución de sus adversarios, expulsándolos de las instancias representativas institucionales y amenazando gravemente su propia existencia.

${ }^{49}$ Carta del 17 de junio de 1857 a Domingo de Oro, reproducida en Scenna, "1874", y Paoli, Sarmiento, 1964, p. 147.
Esta estrategia favoreció, paradójicamente, un acercamiento entre el partido "chupandino" y Urquiza, concretado en vísperas de las elecciones de 1856, el cual habría de profundizarse en los años siguientes, tras la elección de Valentín Alsina -representante de la línea dura del liberalismo- como nuevo gobernador provincial, en 1857.

Los frutos de esta inserción del sistema republicano provincial en un sendero signado por un creciente autoritarismo y la exclusión política de la oposición, comenzarían a recogerse sólo dos años después, el 23 de octubre de 1859, en la batalla de Cepeda, donde las fuerzas de Buenos Aires, comandadas por su ministro de Guerra, Bartolomé Mitre, se mostraron impotentes para afrontar el poderío de las tropas de la Confederación, las cuales, al apoyo moral de los liberales urquicistas sumaban ahora otro, mucho más activo, de buena parte de los "chupandinos" porteños, marginados de las instituciones provinciales.

El Pacto de Unión firmado el 11 de noviembre de 1859 , por el cual Buenos Aires se reintegraba a la Confederación Argentina, expresaba con fidelidad la patética situación de las economías del interior, así como la escasa habilidad de Urquiza para explotar políticamente sus victorias militares; ya que, a cambio de una subvención para las exiguas finanzas de la Confederación, el tratado dejaba a Buenos Aires en inmejorable condición para imponer una serie de reformas al texto constitucional, que se concretarían en 1860 , y que le garantizarían, prác- 
ticamente, la preservación de su autonomía dentro del contexto nacional por un plazo de cinco años.

Para entonces, la debacle de la Confederación era ya irreversible. A la crisis económica y financiera que arrastraba la mayoría de las provincias, la sucesión presidencial de 1860 vino a sumar un creciente antagonismo entre el nuevo presidente, Santiago Derqui, y Urquiza, quien continuaba siendo el hombre fuerte, expresado en una manifiesta fragmentación de las fuerzas políticas del interior. En este contexto, las intrigas políticas que atravesaban el país, en cuya manipulación el nuevo gobernador porteño, Bartolomé Mitre, tendría ocasión de demostrar su mano maestra, condujeron a un nuevo conflicto armado entre Buenos Aires y la Confederación: la batalla de Pavón (17 de septiembre de 1861). Sin embargo, en esta ocasión las tropas comandadas por Urquiza serían llamadas a presurosa retirada, abandonando el campo de batalla ante la mirada incrédula de los efectivos porteños. De este modo, tras casi una década, la hegemonía porteña se reinstalaba en el escenario nacional y, guardando similitud con la jornada del 11 de septiembre y el fracaso del sitio de Hilario Lagos, la victoria poco debía al valor o a las instituciones republicanas de los porteños: en efecto, una vez más, y a despecho de las ingeniosas plumas que pretendieron transmitir para la posteridad esa jornada, el oro de sus florecientes finanzas y la escasa convicción de sus adversarios habrían de constituirse nuevamente en los protagonistas decisivos de la victoria.
CONSENSO Y COERCIÓN: LOS LIMITES DE LAS LIBERTADES CIVILES EN IA REPUBLIICA BONAERENSE DE LOS AÑOS 50

La sanción de la Constitución provincial de 1854 permitía dar forma definitiva a las reglas de juego del nuevo consenso republicano tramado durante el agitado proceso que sucedió a la caída de Rosas. En efecto, en tanto la norma fundamental disponía las estructuras formales de representación, adoptando lo esencial del sistema político instalado en la provincia en 1821 -su principal diferencia consistía en la creación de dos Cámaras dentro de la nueva Legislatura porteña, la de Senadores y la de Diputados-, la participación política retenía una segunda dimensión, vinculada con aquellas prácticas informales que habían florecido en el seno de la lucha por la autonomía porteña -como la prensa, la movilización y el asociacionismo-, y otras ligadas a una sociabilidad más tradicional, de base parroquial, como la beneficencia y las pulperías, o bien de defensa territorial, como la milicia o Guardia Nacional, resignificada en este caso en clave moderna a través de la representación del ciudadano-soldado, el león.

En este contexto, la participación política incorporó prácticas y actores profundamente heterogéneos, construyendo de este modo un consenso considerado indispensable por los actores institucionales y atendiendo a sus peculiares condiciones históricas. ${ }^{50}$ De este modo, producto de la integración entre formas institucionales tra-

\footnotetext{
${ }^{50}$ Halperín, Proyecto, 1978, p. 88.
} 
dicionales y prácticas participativas informales, ${ }^{51}$ el nuevo régimen político sería generoso en sus contradicciones: a cada paso, lo formal y lo informal, lo material y lo simbólico dejaban sus huellas en los comportamientos públicos, componiendo un juego en el cual la puesta en escena adquirió un carácter determinante. ${ }^{52}$

De este modo, el reinado de la opinión pública sobre la política porteña sería reconocido sin mayores objeciones a lo largo de la existencia de la República de Buenos Aires, como lo demuestran, por ejemplo, las expresiones del ministro Carlos Tejedor de 1859:

El gobierno de Buenos Aires es un gobierno de instituciones que reposa en la opinión pública y, para que sea feliz en sus proyectos, es preciso que marche secundado por la opinión. Es preciso establecer la más completa armonía entre las opiniones del gobierno y los representantes legítimos de la opinión pública. ${ }^{53}$

Sin embargo, esto no autoriza a conjeturar la existencia de una cultura política igualitaria. Aun cuando las prácticas políticas de los sectores medios vinculados al proceso de modernización económica hayan comenzado a responder a inspiraciones más progresistas, no se trataría sino de una especie de "nidos" o islas dentro de un universo de tono autoritario $y$ vertical.

${ }^{51}$ Sábato, "Elecciones", 1995.

${ }^{52}$ González, Creation, 1992, t. III.

${ }^{53}$ Diputados, Diario, 4 de mayo de 1859 , p. 4. rancia se advierten a cada paso, sin que puedan identificarse con ninguna facción o círculo en especial, a punto tal que los costos humanos y materiales de la etapa que sucedió a Caseros superaron largamente los producidos por una acción represiva del Estado rosista, amplificada hasta la distorsión por la literatura institucional. En tal sentido, a la violencia clandestina de la mazorca y la severa limitación de la actividad de la prensa, el nuevo régimen parece haber opuesto una justicia parcial -incluso, en ciertas ocasiones, sumaria-, y un respeto diferenciado de las libertades civiles relacionado con la facción política o el sector social de pertenencia.

En efecto, una de las primeras medidas impulsadas por el gobierno de coalición elegido el 24 de julio de 1853, tras la finalización del sitio porteño encabezado por el liberal Pastor Obligado, consistió en hacerse de una justicia adicta, para lo cual decretó el 8 de agosto de ese año la jubilación de los miembros de la Cámara de Justicia nombrada por Urquiza, designando en su reemplazo un nuevo elenco compuesto por liberales septembrinos y ex rosistas. ${ }^{54}$ Esta decisión de subordinar a la Justicia al poder político provincial, estuvo acompañada de una terminante disposición del nuevo gobierno, mediante la cual los jueces de lo criminal y lo civil deberían dar "absoluta preferencia a conocer y juzgar en las causas de los individuos que el gobierno les pase". ${ }^{55}$ Tal preferencia se aplicó in-

${ }^{54}$ En Levene, Historia, 1940, p. 403. 
mediatamente a un difundido caso, denominado "juicio a los mazorqueros", originando un proceso judicial viciado de parcialidad que decidió la ejecución de Ciríaco Cuitiño y otros ocho activos miembros del rosismo, como verdadera medida ejemplificadora para quienes; en el futuro, se atrevieran a poner en cuestión la nueva alianza política labrada entre liberales y ex rosistas. Esta Justicia habría de desempeñar un papel clave a lo largo de la década, acallando los reclamos de la oposición sospechada de vinculación con la Confederación, y convirtiéndose en barrera infranqueable para la difusión de juicios críticos a través de la prensa.

El componente autoritario que distinguía la cultura política de la época puede advertirse, asimismo, en las prácticas de disciplinamiento destinadas a los sectores sociales más rezagados, como el control y la represión de sus formas tradicionales de sociabilidad -v.g. la pulpería, a partir de $1856-,{ }^{56}$ y destinados regularmente a la frontera con el indio, con la consiguiente pérdida de todos sus efectos y bienes personales, consignada por una amplia literatura, ${ }^{57}$ con el consentimiento militante de la nueva dirigencia liberal:

Los gauchos que se resistieron a votar por los candidatos del gobierno -celebraba el primer educador argentino,

${ }^{55}$ Ibid., p. 404.

${ }^{56}$ González, Creation, 1992, t. II, p. 516.

57. La obra característica al repecto es la de Hernández, Martín Fierro, 1974. Un estudio polémico puede consultarse en Shumway, Invención, 1993.
Domingo F. Sarmiento, en 1857, al comentar la estrategia que había diseñado para garantizar la victoria electoral del Partido de la Libertad- fueron encarcelados, puestos en el cepo, enviados al ejército para que sirviesen en la frontera con los indios y muchos de ellos perdieron el rancho, sus escasos bienes y la mujer. ${ }^{58}$

También en un terreno escasamente explorado: el de los procedimientos adoptados para garantizar una subordinación de lo privado a lo público en las instancias críticas. $\mathrm{Al}$ respecto, puede señalarse por ejemplo que, ante la verificación del Sitio de Lagos, la estrategia oficial no se limitó a sancionar el estado de sitio, disponer el cavado de trincheras o bien efectuar una distribución adecuada de las tropas. La convocatoria de los leones porteños avanzó resueltamente sobre los derechos civiles, en tanto que la declaración de la plaza en Estado de Asamblea permanente permitió crear las condiciones adecuadas para la promoción del repudio público de quienes no estuviesen a la altura de sus responsabilidades de ciudadanosguerreros: las medidas a aplicar en estos casos incluían el destino por dos años en el servicio de frontera, el despido de sus empleos y la eliminación de la lista militar, la declaración de nulidad en eventuales enajenaciones, hipotecás y transferencias realizadas, la violación legal de domicilio a fin de llevar a la fuerza a los.no comparecientes y la deportación de quienes se

${ }^{58}$ Carta del 17 de junio de 1857 a Domingo de Oro, reproducida en Scenna, "1874"; Paoli, Sarmiento, 1964, p. 147. 
sospechase estuvieran vinculados al enemigo. ${ }^{59}$

\section{La prensa republicana}

Uno de los terrenos en que este componente coercitivo de la cultura políti-, ca de los 50 resultó más explícito, fue el de la prensa. En efecto, si bien una de las primeras medidas adoptadas después de Caseros fue la derogación de la ley de imprenta sancionada por el gobierno de Rosas -verdadero gesto político que apuntó a instalar colectivamente la naturaleza de los nuevos tiempos, y la profundidad del cambio que se avecinaba-; la norma que la reemplazó -sancionada originalmente en 1828 y denominada popularmente como ley "mordaza"-, proveyó de una herramienta maestra para recortar el ejercicio de la crítica, al prever la fijación de pesadas multas para los in-

${ }^{59} \mathrm{La}$ denuncia de la existencia de un plan de Urquiza para inquietar el orden daría lugar a un jugoso debate, que aporta interesantes elementos de juicio al respecto:

" - Sr. ministro de Hacienda: Cuando el gobierno delegado dirigió la nota lo hizo en virtud de los repetidos antecedentes que tenía de haber un plan para inquietar al orden, sostenido por el general Urquiza, el que subsidia un periódico de esta capital; sabía los conciliábulos que se formaban para excitar el descontento, dando esperanzas ilusorias a unos y promoviendo la desconfianza en otros: que los agitadores eran algunos de los que nos han combatido, y otros deseosos de novedades y revueltas. La actual ley de imprenta, cuya pena es insignificante, de nada sirve para reprimir esos desmanes por la prensa.

$-\mathrm{Sr}$. Montes de Oca: Como miembro de la Comisión, diré que no ha sido la mente de ésta conceder facultades extraordinarias al gobier- fractores, la clausura de medios opositores y aun la alternativa de la cárcel y el destierro de sus editores.

En contraposición con esta afirmación se levantan los juicios establecidos por la historiografía institucional, de Sarmiento en adelante, coincidentes en alabar la vigencia de una plena libertad de prensa en Buenos Aires tras la caída del rosismo. Para Ricardo Levene, por ejemplo, el "triunfo de Caseros significó, entre otras cosas, quitar la mordaza que trababa la dignidad periodística", ${ }^{60}$ juicio que se contradice con su argumentación posterior, en que documenta la utilización por parte de la prensa porteña, durante el tutelaje de Urquiza, de un discurso que computaba como errores u omisiones sus gestos autoritarios a fin de garantizar una continuidad puesta en cuestión. Ramón J. Cárcano, por su parte, posterga el inicio de ese proceso al "[...] 11 de septiem-

no; pero siendo delicada la situación del país, debe autorizarse al gobierno para salvarla.

-Sr. Alsina: Si la Sala da crédito a las observaciones del gobierno, es preciso obrar en consecuencia; se puede poner en conflicto algunas de las garantías individuales; pero el deber de los representantes es atender antes a las públicas, por el que el país está sobre el individuo."

Como conclusión se decide redactar la siguiente minuta: "El gobierno a quien está encomendad a la tranquilidad pública que tanta sangre y sacrificios cuesta a sus buenos hijos y de cuya continuación dependen tan vitales intereses, queda plenamente autorizado para destituir, arrestar y extrañar fuera de la provincia a los que pretendan perturbar el orden público dando cuenta a la honorable Sala, dentro de ocho días." Cámara de Senadores de la Provincia de Buenos Aires, Diario de Sesiones, 3 de abril de 1854, pp. 107-108.

${ }^{60}$ Levene, Historia, 1940, p. 377. 
bre, [que] creó el poder de la crítica, con fuerza para hacerse escuchar y entender". ${ }^{61}$ Entre los estudios más recientes, Tim Duncan arriba a una conclusión similar para la década del 80 , sin ofrecer elementos de juicio contundentes. ${ }^{62}$

Debido a su centralidad, resulta necesario analizar esta cuestión en detalle. Desde la época de la oposición a Rosas, la guerra periodística desarrollada entre ambas márgenes del Plata alcanzó altos decibeles, cuyos ecos se extendieron a las principales capitales europeas. ${ }^{63}$ Durante la campaña del Ejército Grande, la decisión de Urquiza de contar con un boletín propagandístico sería sostenida al extremo de aceptar para él, la incómoda presencia de un Sarmiento, aún más fanatizado en sus predicciones sobre los efectos destructivos que su imprenta "fulminante" estaba destinada a causar en el régimen rosista. ${ }^{64}$ Después de Caseros, y a pesar de los pronósticos optimistas, el pleno disfrute de la libertad en el ámbito de la prensa estaba aún lejos de alcanzarse. Según Alberdi, la cuestión consistía en "[...] saber qué pedía antes la política a la prensa, y qué le pide hoy desde la caída de Rosas". ${ }^{65}$ Para resolverla, recomendaba recurrir a la experiencia disponible:

¿Cúal fue la conducta de la revolución respecto de la prensa -se preguntaba-,

${ }^{61}$ Cárcano, Caseros, 1918, p. 212.

${ }^{62}$ Duncan, "Prensa", 1980.

${ }^{63}$ Véase, Weinberg, "Prensa", 1974; Saldías, Historia, 1987, t. II, Pp. 354 y ss.

${ }^{64}$ Sarmiento, Campaña, 1957, p. 11.

${ }^{65}$ Alberdi, Cartas, 1932, p. 13. en los años que siguieron a 1810 y a 1820? Exclusiva y celosa, o mas bien, decididamente política. La consagró exclusivamente al servicio de su causa, al grande objeto de crear la autoridad nacional. [...] Una ley de 26 de octubre de 1810 proclamó el principio de la libertad de prensa; pero fue entendido que ese principio no sería empleado contra la revolución de mayo y en defensa de los opositores españoles a la nueva autoridad patria. El abuso de la libertad fue declarado crimen; y se declaró abusivo todo escrito que comprometiese la tranquilidad o la constitución del Estado. En una palabra, la prensa sólo fue libre para defender la revolución de mayo. [...] He ahí-concluía- la única prensa que hará posible la creación de la autoridad en la situación presente de la República Argentina: la prensa de Moreno y de Rivadavia, de 1810 y de 1821 . La prensa que hoy permite ocuparse de colonización y de ferrocarriles a la Francia, a la España y a Chile; la prensa que tiene poder para ilustrar a la sociedad, pero no para destruirla y ensangrentarla. ${ }^{66}$

Sin embargo, aun cuando esa prensa encorsetada dentro de límites tan estrechos resultase, para Alberdi, la más apropiada para contribuir a la organización política de la República, su efectividad sólo podría ser consecuencia de la fijación de estrechos márgenes para su expresión. No haría falta andar mucho para que el periodismo porteño tuviera que afrontar las sanciones que acompañaban a esas restricciones, en tanto el disenso en tono irónico explotado por $E l$ Nacional de Vélez Sarsfield y Los Debates de Mitre

${ }^{66}$ Alberdi, Elementos, 1918, pp. 351-353. 
durante las Jornadas de Junio de 1862 recibió, como primitiva e inmediata respuesta, la clausura, la deportación y la imposición de la censura previa, decretándose posteriormente el fin de la crítica como condición de posibilidad para los medios escritos. ${ }^{67}$

Poco tiempo después, ante la consolidación de la secesión porteña y la conformación de los dos Estados antagonistas en suelo argentino -Buenos Aires y la Confederación-, Alberdi evaluaría los resultados de su propia receta, sin hacerse cargo de ello:

No pretendo desconocer que hay contradicción y debate en esa prensa. Lo que niego es que esos debates sean pruebas de libertad. Hay dos opiniones en choque, porque hay dos gobiernos incompatibles. Cada opinión es libre para atacar al gobierno rival en defensa del gobierno propio, es decir, que ambas son oficiales. Nadie es libre para atacar a los dos gobiernos, en defensa de la nación explotada por ambos. ${ }^{68}$

Sin faltar a la verdad, esta descripción no se esfuerza por trazar una distinción cualitativa entre la prensa de la Confederación y la de Buenos Aires. En el primer caso, la libertad de acción de editores y redactores era prácticamente inexistente, en virtud del estrecho lazo que los unía con las autoridades confederadas, debido a su condición de empleados a sueldo o inestables licenciatarios. Néstor de Auza $^{69}$ y Tulio Halperín Donghi ${ }^{70}$ han

${ }^{67}$ Levene, Historia, 1940 , p. 380.

${ }^{68}$ Alberdi, Obras, t. vI, p. 394.

${ }^{69}$ Auza, Periodismo, 1978, p. 225.

${ }^{70}$ Halperín, José Hernández, 1987, p. 287. diseccionado puntillosamente las características de esa relación. Por el contrario, en Buenos Aires, los límites para el ejercicio de la libertad de prensa parecen haber sido un tanto más flexibles, aun cuando no demasiado amplios, dependiendo en buena medida de las solidaridades personales de los editores y la evolución del equilibrio político.

Al respecto, resulta pertinente efectuar un breve repaso sobre las trayectorias de Nicolás Calvo y Juan Francisco Monguillot, que permite ilustrar adecuadamente la relación entre periodismo y política. Mientras estuvo en vigencia el acuerdo entre rosistas y liberales, Nicolás Calvo, redactor de La Reforma Pacífica, no encontró mayores inconvenientes para desarrollar una decidida prédica profederal en Buenos Aires. Sin embargo, a partir de las elecciones de 1854, que enfrentaron a liberales y federales -o "pandilleros" y "chupandinos", respectivamente, de acuerdo con la designación popular adoptada en ese momento-, las diferencias entre los rivales históricos comenzarían a profundizarse. En efecto, en tanto el liberalismo se apoderaba de manera creciente del aparato provincial en escorzo, los ex rosistas debieron acercarse cada vez más a Urquiza, intentando revertir su declinante posición como fuerza política, así como asegurar su propia vida ante la política de violencia y amenazas desplegada por sus adversarios, quienes controlaban el andamiaje estatal. La evolución de esta situación, agravada en las proximidades de las elecciones de representantes de 1856 y 1857 , en las cuales 
debía definirse la composición de la Sala que debería elegir al nuevo gobernador, expuso a Calvo a la necesidad de aceptar una embarazosa contribución de Urquiza para continuar con la publicación de su popular periódico, habida cuenta de que las subvenciones y créditos oficiales se habían cerrado para él. Como respuesta; la amañada Justicia del Estado de Buenos Aires dispuso la clausura del medio. El fracaso del joven Monguillot, en tanto, sería mucho más inmediato, ya que su atrevido intento de difundir la causa confederada en Buenos Aires por medio de La Prensa, también con el financiamiento del presidente Urquiza, habría de concluir con la fijación de una multa de 8000 pesos, la inhabilitación por dieciséis meses y la amenaza de destierro por cuatro años. De ambos ejemplos puede extraerse que no sólo el discurso crítico, sino las circunstancias históricas y, fundamentalmente, los personajes o grupos de interés que respaldaban financieramente a un periódico, constituían los elementos de juicio decisivos para determinar su continuidad o clausura.

La financiación de la prensa adquirió, asimismo, un carácter central, habida cuenta de la habitual estrechez económica a que se veían sometidos los editores, falencia que incidiría regularmente en el posicionamiento político de los periódicos. La compleja y estrecha relación establecida entre editores y poder político, satisfaciendo intereses mutuos, implicó un grave detrimento para la libertad de expresión. En efecto; a nadie escapaba la importancia capital de disponer de un fácil acceso a esos canales claves den- tro del proceso de formación de la opinión pública, los medios gráficos, dentro de una cultura predominantemente escrita, como la del siglo XIX.

El acceso a los fondos públicos facilitaba significativamente ese objetivo. Al respecto, Valentín Alsina enviaría a su ministro Bartolomé Mitre, el 25 de abril de 1858, una carta sumamente expresiva:

Sabe usted que el fondo anual para suscripciones e impresiones es solamente 240000 pesos. El gobierno está suscrito hoy a La Tribuna (por contrato), El Nacional, Los Debates, British Packet, Espada, Regeneración, Opinión Pública, Aniceto, Comercial Times, Mosaico Poético, la obra de Nuñez, Celebridades y qué se yo cuántas otras (y no hablo aquí de "impresiones"); de modo que aun sin contar que las nuevas suscripciones sean "forzosas" en el resto del año, es muy difícil que alcance la suma. ${ }^{71}$

A tales condicionamientos para el ejercicio de la libertad de expresión, se sumaba una práctica perversa de los propios redactores, consistente en utilizar su influencia ante las autoridades para resolver sus conflictos dentro del campo de la prensa. Sobre el tema, resulta significativa la misiva que Mariano Varela le enviara al fiscal Rufino de Elizalde el 27 de junio de 1860 :

Si yo tuviera influencia con Vd. le pediría que acusase a La Reforma que presta sus columnas a un muchacho sin reflexión, para que cometa delitos, pues es un delito lo que ha hecho. Ma-

${ }^{71}$ En Auza, Periodismo, 1978, p. 23. 
ñana yo pienso escribir en La Tribuna al respecto. ${ }^{72}$

Según puede extraerse de los elementos de juicio expuestos, lejos de reivindicar la "dignidad periodística" o quitar la "mordaza para el ejercicio de la crítica", los límites al ejercicio de la libertad de expresión vigentes en la República de Buenos Aires en los años 50 fueron sumamente acotados. En lo referido a la política interna, el discurso tolerable aceptó una serie de variaciones sobre una base común que exaltaba los valores republicanos y provinciales en cuanto al repudio del antagonista/externo. Mientras tanto, ninguna descalificación resultaba excesiva. Como se ha visto, la aplicación de la ley "mordaza" del año 1828 resultó, en manos de una justicia accesible, un instrumento sumamente eficaz, que la experiencia permitiría ir perfeccionando en detrimento de las libertades públicas. En tal sentido, la reforma auspiciada por el ministro Sarmiento en el año 1857, durante el segundo mandato de Valentín Alsina, por la que se sometía a la prensa a los tribunales ordinarios, causaría estragos durante una década:

Las acciones de los particulares por injurias, calumnias o difamaciones que se cometan por la prensa, como también las que en su caso corresponda intentar a los fiscales del Estado, podrán ser deducidas ante los jueces ordinarios, los cuales la juzgarán por las leyes civiles o criminales. ${ }^{73}$

${ }^{72}$ Instituto Ravignani, Elizalde, 1974 , pp. 523-524.

${ }^{73}$ El argumento del gobierno era el siguiente: "Señor Sarmiento: Por la combinación de
De este modo, el ejercicio del disenso dentro de la República de Buenos Aires, parece haber encontrado límites efectivamente estrechos, producto de la pervivencia de una cultura política autoritaria que encontraba problemática su correspondencia con las instituciones y los valores republicanos. Este avance del Estado sobre las libertades civiles quedaría adecuadamente patentizado en el gravoso balance que el diputado València formuló sobre la gestión de Pastor Obligado, recientemente concluida, mirando el futuro sin mayores esperanzas:

Hay cargos muy graves contra la última administración. El Sr. Obligado ha violado la Constitución, no ha asegurado las garantías individuales, ha atacado la

varias causas ha venido a suceder en Buenos Aires que no hay tribunal, ha dejado de reunirse, de manera de ser hoy en día una cosa sentada en Buenos Aires que no había jurado, de manera que todas las causas que se inician ante él, concluyen sin ser vistas siquiera. Por esa razón he creído, para remover un obstáculo insuperable como ese, debían traerse las causas a los tribunales ordinarios. [...] ¿quién forma el jurado? Entre nosotros ha sido práctica designar a cien personas, no sé si son sesenta en Buenos Aires, y donde hay cierto espíritu en la sociedad en cada momento en que se hace la elección de las personas, sucede que las sesenta ya son decididamente cómplices de algunos de los partidos políticos. De donde resulta que el juez ya es cómplice.[...] Creo, pues, que los delitos cometidos por la prensa, deben ser tratados como el simple libelo." Senadores, Diario, 15 de septiembre de 1857 , pp. 346349: La ley sería aprobada sin dilación, y sus efectos sobre la libertad de expresión serían funestos, tanto durante los cincuenta como a lo largo de la década de los sesenta, siendo designada regularmente como la "ley bárbara del 57". Al respecto, Véase Lettieri, "Construcción", 1995. 


\section{SECUENCIA}
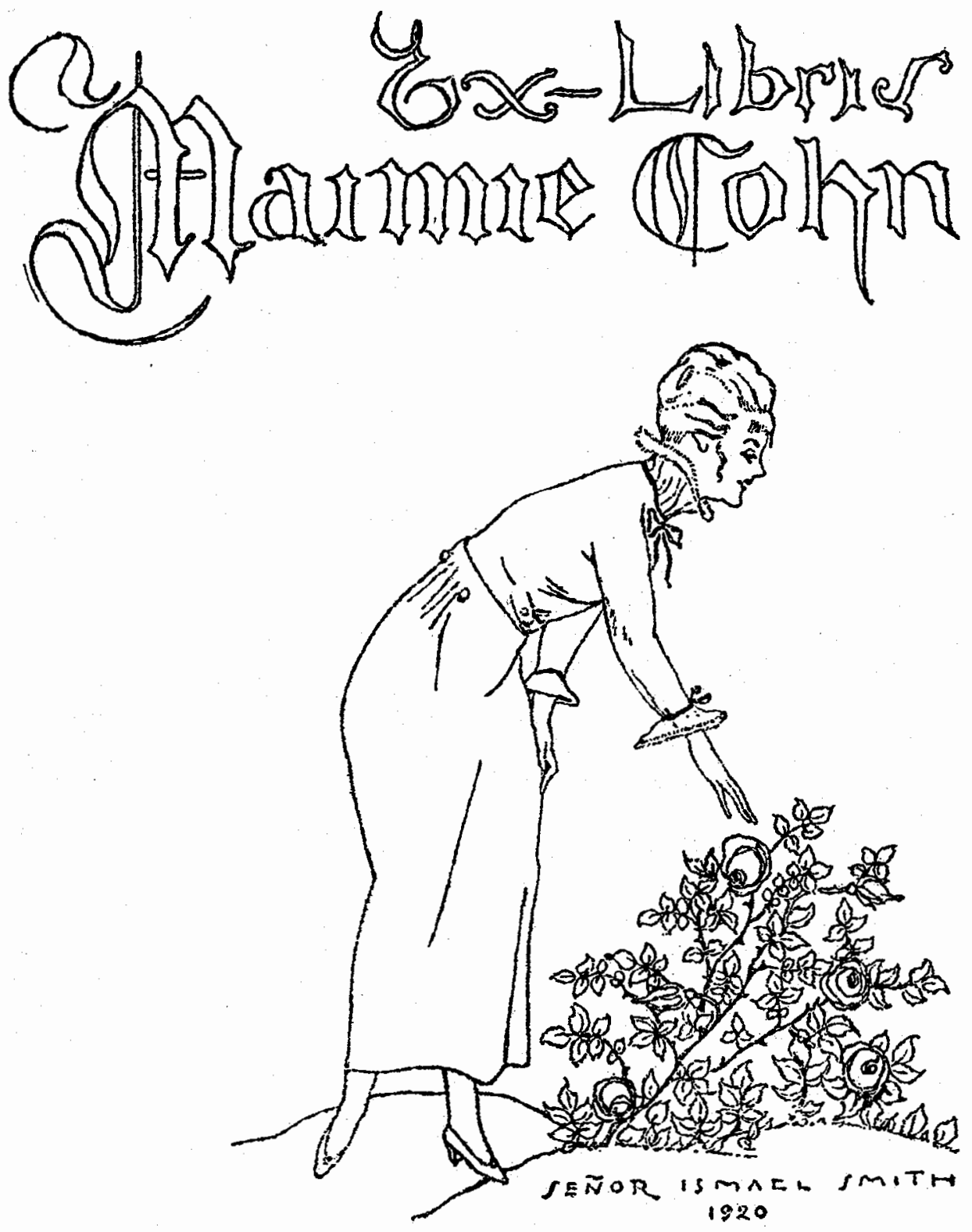
libertad de imprenta persiguiendo a varios periodistas como los de La Crónica, cerrando imprentas, en menoscabo de la libertad de industria y del derecho de propiedad; ha creado empleos y dispuesto de los caudales públicos, sin sujeción al presupuesto; ha dejado indefensa la frontera, arriesgando las vidas y las fortunas, por la ineptitud de sus consejeros. ${ }^{74}$

\section{CONCLUSIONES}

En este artículo se ha intentado estudiar las características del sistema de legitimación del régimen político republicano de la Provincia de Buenos Aires en la década que sucedió a la batalla de Caseros, prestando especial atención al lugar asignado a la opinión pública. Según he intentado demostrar, la necesidad de garantizar una cohesión interna suficiente para enfrentar una latente amenaza de agresión por parte de fuerzas militares manifiestamente superiores, condujo a una heterogénea dirigencia provincial a intentar superar las divisiones fratricidas del pasado estableciendo consensos, tanto en su interior -sumando a liberales y ex rosistas con vocación autonómica-, como con respecto a una sociedad civil desgarrada después de casi medio siglo de autoritarismo y violencia.

Para ello, la estrategia de formación de una activa opinión pública, que compartiera una comunidad de sentimientos y objetivos con la nueva p. 52 .

${ }^{74}$ Diputados, Diario, 6 de junio de 1857 , clase política, descansó sobre el diseño de un marco disuasivo/coercitivo para el ejercicio de la disidencia, cuyas herramientas principales fueron la ley de imprenta de 1828 y una justicia decididamente subordinada al situacionismo político. Una vez garantizadas esas condiciones, el impulso a una participación activa en el espacio público -induciendo a la práctica de las nuevas formas de sociabilidad, en particular, de la movilización colectiva-, permitió ir definiendo un imaginario provincial que se erigió en uno de los principales reaseguros para la reproducción del sistema. Ese imaginario, que reconocía las marcas del interés de los grupos dirigentes en asegurarse una opinión pública adicta, adoptó desde un principio ciertos mecanismos de participación de la democracia directa, haciendo hincapié en su capacidad de legitimación de la autoridad política.

La asignación de ese papel protagónico a una opinión pública ampliadà, atribuible sobre todo a las urgencias impuestas por el sitio de Lagos, sería puesto en cuestión en los años subsiguientes, sin obtener resultados terminantes. En efecto, el aligeramiento del acecho externo no consiguió diluir del todo la amenaza latente de nuevas incursiones armadas, lo cual potenciaba los riesgos de debilitar esa poderosa comunidad de sentimientos e intereses en el caso de ponerse en cuestión uno de sus componentes nucleares. Más aún, según permitirían reafirmarlo las agitadas jornadas que acompañaron el cambio de década, era justamente esa opinión la base primordial de una dirigencia 
que gustaba presentarse como cívicoguerrera, aun cuando sus méritos en el terreno armado permitiesen esbozar más de una sombra de duda. ${ }^{75}$

De cualquier modo, afirmar que la opinión pública constituyó, durante los años 50 , un verdadero ámbito de legitimación universalmente aceptado, no implica formular una sobreváloración de las inspiraciones igualitarias en la República porteña. Por ejemplo, la práctica desembozada del fraude que acompañó la regularización del ejercicio electoral en Buenos Aires, se convirtió en una condición estructural para garantizar el monopolio del poder político dentro de una elite estre-

\footnotetext{
${ }^{75}$ Un ejemplo contundente al respecto es el siguiente. Ante la zozobra permanente que experimentaba la campaña durante el año $\mathbf{1 8 5 5}$, Bartolomé Mitre, en su calidad de ministro de Guerra de la provincia, decidió encabezar personalmente la represión, afirmando: "Respondo hasta la últina cola de vaca de la provincia de que en adelante roben más los salvajes." Sin embargo, su enfrentamiento con el cacique Catriel, en Sierra Chica, terminaría con una aplastante derrota de las fuerzas provinciales, que abandonaron además su arsenal y caballada en manos de los indios. Sin embargo, el parte de acción redactado por Mitre en la ocasión, buscaría dejar a salvo sus virtudes militares, afirmando haberse enfrentado con "la confederación más vasta de tribus del desierto que haya tenido lugar desde el tiempo de la conquista". Comentando esos sucesos, Juan María Gutiérrez escribiría una irónica carta a Urquiza: "Parece que el coronel Mitre no es hómbre que gusta mucho del despoblado. Lo hemos visto, después de su descalabro delante de los indios $y$ cuando el honor le mandaba quedarse en la campaña hasta vengarse de los que lo habían obligado a quedarse de a pie, mandarse mudar a Buenos Aires." Pese a ello, su popularidad no habría de decaer. Véase Páez, Derrumbe, 1982, pp. 60-62.
}

cha. De este modo, aun cuando candidaturas, liderazgos y políticas fuesen sometidos regularmente a la aprobación dél criterio público -lo cual implicaba, de todos modos, un significativo avance-, la injerencia oficial sobre los mecanismos de formación de opinión a través de diversas prácticas, que iban de la subvención de los medios a la coerción directa, nunca descendió, destinándose una creciente porción del presupuesto a esos fines.

El equilibrio artesanal labrado durante la primera mitad de los 50 bajo condiciones de producción específicas, que he caracterizado como ciudad sitiada, entraría en franco colapso a partir de 1856 , una vez entrados en vigencia los Pactos de Convivencia firmados con la Confederación en 1854 y 1855. En efecto, lejos de potenciar la estabilidad del sistema, el debilitamiento de una efectiva presión externa alimentaría una voracidad desembozada entre los círculos liberales encaramados en las instituciones provinciales durante la administración de Pastor Obligado. Tales pretensiones conducirían a la ruptura del consenso faccioso existente, al colocar a los núcleos de "chupandinos" en la drástica alternativa de aceptar una integración subordinada al orden político provincial o de negociar el apoyo del general Urquiza. En este sentido, las elecciones provinciales de 1856 y 1857 -decisivas para la designación del nuevo gobernador-, permitirían refrendar la hegemonía liberal en la provincia, recurriendo al avasallamiento de la moral y los derechos públicos.

Sin embargo, aun cuando. la ruptura del consenso faccioso parece ha- 
ber estado acompañada de un avance del Estado provincial sobre la sociedad civil, ello no habría de transformar sustancialmente el sistema de valores y prácticas públicas que habían sustentado al sistema republicano a partir del 11 de septiembre. En verdad, tanto el temor ante el evidente acercamiento entre los núcleos de "chupandinos" y el general Urquiza, como el interés compartido entre los gobernantes y la sociedad civil por acrecentar la prosperidad económica, parecen haber significado otros tantos elementos de juicio irrebatibles en el momento de renovar ese consenso entre la opinión pública y su dirigencia cívico-guerrera, ocluyendo sus falencias estructurales para reprimir las correrías de los indios pampas o enfrentar con éxito en el terreno de las armas a las tropas confederadas.

Con la elección de Valentín Alsina, el proceso de unificación de la nación entraba en su etapa final, recortándose sustancialmente los espacios de la negociación política. Producto natural de este proceso, la batalla de Cepeda ofrecería la última oportunidad para organizar una nueva Argentina en clave confederal. Sin embargo, ya para ese entonces el crecimiento material de Buenos Aires le confería una importancia tal en el contexto nacional, que le permitiría transformar su derrota en victoria en la mesa de negociaciones, sin mayores inconvenientes. Dos años después, en la batalla de Pavón, el abandono del campo de batalla por las tropas de Urquiza expresaba la resignación e impo- tencia de buena parte del interior ante la imposibilidad de revertir un proceso que conducía inequívocamente hacia la consumación de la soberanía porteña.

La decisiva modificación del equilibrio de fuerzas que acompañó el cambio de década habría de poner en cuestión el futuro de la arquitectura del régimen político bonaerense, al modificarse sus condiciones sistémicas. En efecto, la necesidad de formular una política y, luego de Pavón, las bases de un nuevo proyecto integrador en clave nacional -algunos de cuyos ejes comenzaban a adivinarse en la estrategia contemporizadora que anunciaban los actos del gobernador y futuro presidente Bartolomé Mitre-, en poco parecían coincidir con las demandas de la dirigencia y la opinión pública mayoritaria en Buenos Aires, imperturbables en su reclamo de aniquilamiento del enemigo derrotado. Una vez reconocida su hegemonía a nivel nacional, los nuevos tiempos traían consigo la necesidad de adaptar a esa República porteña al nuevo equilibrio político que comenzaba a redefinirse a nivel nacional. Mientras tanto, las agudas tensiones que afectaban a la dirigencia porteña parecían anticipar un porvenir desolador, a partir de la fundada sospecha de que la victoria sobre la confederación podía encubrir, paradójicamente, una amenaza para su autonomía y sus instituciones republicanas mucho más grave que la significada en el pasado por las tropas y las armas de sus adversarios. 
HEMEROGRAFIA

El Comercio del Plata (1848-1851)

El Nacional (1852-1861)

La Prensa (1857)

La Reforma Pacífica (1855-1859)

La Tribuna $(1854-1861 ; 1869)$

Los Debates (1852; 1857-1858)

\section{BIBLIOGRAFIA}

-Alberdi, Juan Bautista, Las bases, ed. Plus Ultra, Buenos Aires, 1984.

Cartas quillotanas, La Cul-

tura Argentina, Buenos Aires, 1932.

Elementos del derecho público provincial, Ed. del Ateneo, Buenos Aires, 1918.

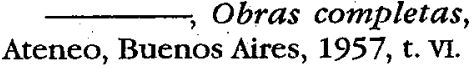

-Auza, Néstor T. de, El periodismo de la confederación, 1852- 1861, EUDEBA, Buenos Aires, 1978.

-Botana, Natalio R., El orden conservador. La política argentina entre $1880 y$ 1916, Ed. Sudamericana, Buenos Aires; 1985.

-Bustamante, José Luis, Memorias sobre la revolución del 11 de septiembre de 1852, Imprenta del Comercio, Buenos Aires, 1853.

-Cárcano, Miguel Ángel,Sáenz Peña. La revolución por los comicios, EUDEBA, Buenos Aires, 1976.

-Cárcano, Ramón J., De Caseros al 11 de septiembre, Ed. Viau y Cía., Buenos Aires, 1918.

-Chiaramonte, José Carlos, "Vieja y nueva representación: los procesos electorales en Buenos Aires: 1820-1840" en Antonio Annino, (coord.), Historia de las elecciones en Iberoamérica, siglo $X I X$, FCE, Buenos Aires, 1995, pp. 19- 64.

-D'Amico, Carlos, Buenos Aires, sus bombres, su política (1860-1890), Ed. Americana, Buenos Aires, 1967.
Duncan, Tim "La prensa política: 'SudAmérica', 1884-1892" en Gustavo Ferrari y Ezequiel Gallo (comps.), La Argentina del ocbenta al centenario, Ed. Sudamericana, Buenos Aires, 1980, pp.761-784.

-González Bernaldo, Pilar,"Pedagogía societaria y aprendizaje de la Nación en el Río de la Plata" en A. Annino y F. Guerra, De los imperios a las naciones. Iberoamerica, Ibercaja, Zaragoza, 1994, pp. 332357.

- "La creation d'une nation. Histoire politique des nouvelles appartenances culturelles dans la ville de Buenos Aires entre 1829 et 1862 ", tesis doctoral, Université de Paris I, Pantheon-Sorbonne, 1992, t. III, mimeografiado.

-Halperín Donghi, Tulio, José Hernández y sus mundos, Ed. Sudamericana, Buenos Aires, 1987.

- Proyecto y construcción de una nación (1846-1880), Biblioteca Ayacucho, Caracas, 1978.

, "Liberalismo argentino y liberalismo mexicano: dos destinos divergentes" en El espejo de la bistoria, Ed. Sudamericana, Buenos Aires, 1987, pp. 141-166.

-Hernández, José, Martín Fierro, Ed. Kapelusz, Buenos Aires, 1974.

-Instituto de Historia-Facultad de Filosofía y Letras-Universidad de Buenos Aires, El doctor rufino de Elizalde a través de su archivo, t. 4, 1974.

-Legislatura de la Provincia de Buenos Aires, Cámara de Senadores, Diario de sesiones, periodo 1854-1861.

-Legislatura de la Provincia de Buenos Aires, Cámara de Diputados, Diario de sesiones, periodo 1854-1861.

-Lettieri, Alberto R., Vicente Fidel López. La construcción bistórico-politica de un liberalismo conservador, Ed. Biblos, Buenos Aires, 1995 (Col. Simón Rodríguez).

La formación del sistema politico moderno. Legitimidad, opinión 
pública y discurso parlamentario. Argentina 1862- 1868, Facultad de Filosofía y Letras-Universidad de Buenos Aires, 1995 (Col. Cuadernos del Instituto Ravignani).

"La construcción del consenso en los inicios del sistema político moderno argentino (1862-1868)", Anuario de Estudios Americanos, 1995, Sevilla, pp. 151-177.

-Levene, Ricardo (coord.), Historia de la provincia de Buenos Aires y formación de sus pueblos, vol. I, Taller de Impresiones Oficiales, Publicaciones del Archivo Histórico de la Provincia de Buenos Aires, La Plata, 1940.

-Mitre, Bartolomé, Historia de Belgrano $y$ de la independencia Argentina, EUDEBA, Buenos Aires, 1968.

-Myers, Jorge, Orden y virtud. El discurso republicano en el regimen rosista, Universidad Nacional de Quilmes, Buenos Aires, 1995.

-Páez de la Torre, Carlos, El derrumbe de la confederación. 1855-1862, Ed. La Bastilla, Buenos Aires, 1984.

-Paoli, Pedro de, Sarmiento. Su gravitación en el desarrollo nacional, Ed. Theoría, Buenos Aires, 1964.

-Ravignani, Emilio (comp.), Asambleas constituyentes argentinas, Talleres S.A. Jacobo Peuser Ltda., Buenos Aires, 1937, t. IV.

-Sábato, Hilda, "Ciudadanía, participación política y la formación de la esfera pública en Buenos Aires, 1850-1880", Entrepasados, año $\mathrm{IV}$, núm. 6 , comienzos de 1994, pp.65-88.

, "Elecciones y prácticas electorales en Buenos Aires, 1860-1880. ¿Sufragio universal sin ciudadanía política?" en Antonio Annino (coord.), Historia de las elecciones en Iberoamerica, siglo XIX, PCE, Buenos Aires, 1995, pp.107142. y E. Palti, "¿Quién votaba en Buenos Aires? Práctica y teoría del sufragio, 1850-1880", Desarrollo Económico, núm. 119, oct.-dic. 1990, pp. 395-424.

-Sáenz Quesada, María, La república dividida, 1852-1855, Ed. La Bastilla, Buenos Aires, 1979.

-Sala de Representantes de la Provincia de Buenos Aires, Diario de sesiones, periodo 1852-1854.

-Saldías, Adolfo, Historia de la confederación argentina, Hyspamérica, Buenos Aires, 1987.

$\therefore$ Un siglo de instituciones, Hyspamérica, Buenos Aires, 1987.

-Sampay, Arturo E., Las constituciones de la Argentina (1810/1972), EUDBBA, Buenos Aires, 1975, t. I y II.

-Sarmiento, Domingo F., Argirópolis, en Obras Completas, t. vII, Ed. Luz del Día, Buenos Aires, 1950.

- Campaña en el ejército grande, Ed. Kraft, Buenos Aires, 1957.

Buenos Aires, 1979. Facundo, Ed. Kapelusz,

-Scenna, Miguel Ángel, "1874: Mitre contra Avellaneda", Todo es Historia, núm. 74, pp. 4-35.

-Shumway, Nicolás, La invencion de la Argentina. Historia de una idea, Emecé Ed., Buenos Aires, 1993.

-Terán, Oscar, "El liberalismo argentino", Punto de Vista, núm. 50, nov. 1994, pp. 27-31.

-Ternavasio, Marcela, "Nuevo régimen representativo y expansión de la frontera política. Las elecciones en el Estado de Buenos Aires: 1820-1840", en Antonio Annino (coord), Historia de las elecciones en Iberoamérica, siglo XIX, $\mathrm{FCE}$, Buenos Aires, 1995, pp. 65-106.

-Weimberg, Félix, "La prensa en la época de Rosas", en E. M. Barba y otros, Unitarios y federales, Ed. Gránica, Buenos Aires, 1974, pp. 51-83. 


\section{DOROTHY}

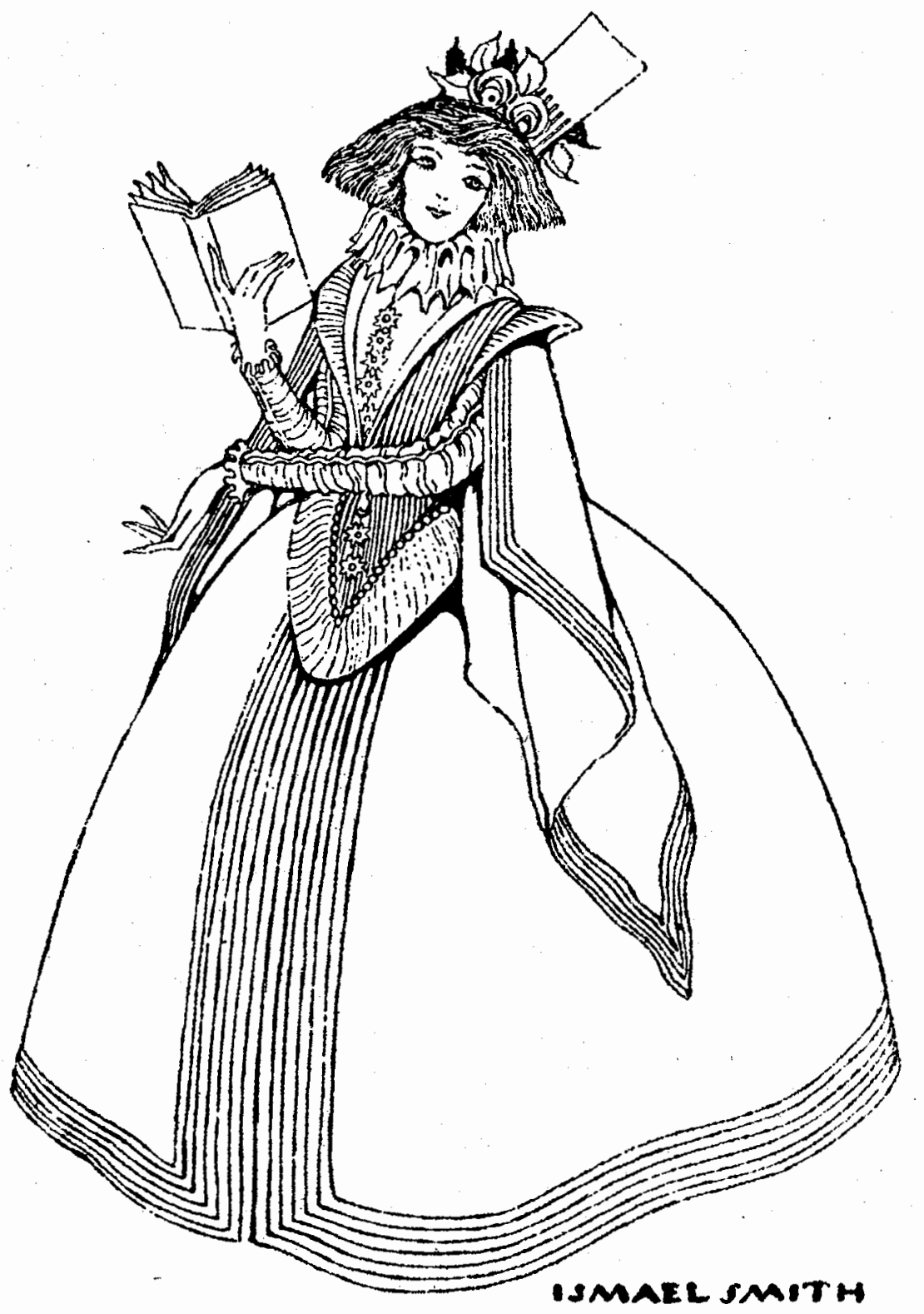

$E X \sim L I B R I S$ 